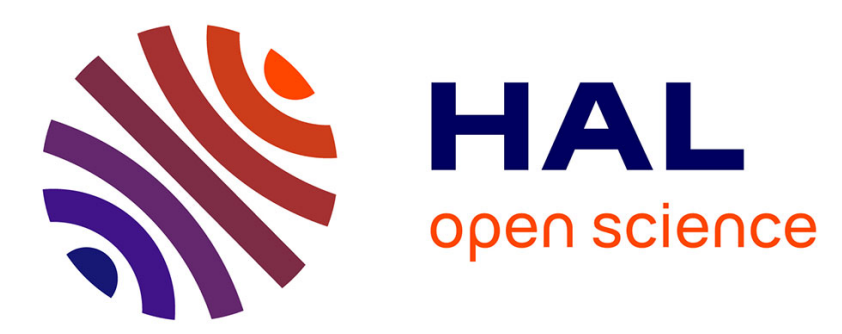

\title{
Lead content and isotopic composition in submound and recent soils of the Volga upland
}

Tatiana Pampura, Anne Probst, Dmitry V. Ladonin, Vitaly A. Demkin

\section{To cite this version:}

Tatiana Pampura, Anne Probst, Dmitry V. Ladonin, Vitaly A. Demkin. Lead content and isotopic composition in submound and recent soils of the Volga upland. Agricultural Chemistry / Agrokhimiya, 2013, vol. 46 ( $\left.\mathrm{n}^{\circ} 11\right)$, pp. 1059-1075. 10.1134/S1064229313090020 . hal-01177620

\section{HAL Id: hal-01177620 \\ https://hal.science/hal-01177620}

Submitted on 17 Jul 2015

HAL is a multi-disciplinary open access archive for the deposit and dissemination of scientific research documents, whether they are published or not. The documents may come from teaching and research institutions in France or abroad, or from public or private research centers.
L'archive ouverte pluridisciplinaire HAL, est destinée au dépôt et à la diffusion de documents scientifiques de niveau recherche, publiés ou non, émanant des établissements d'enseignement et de recherche français ou étrangers, des laboratoires publics ou privés. 


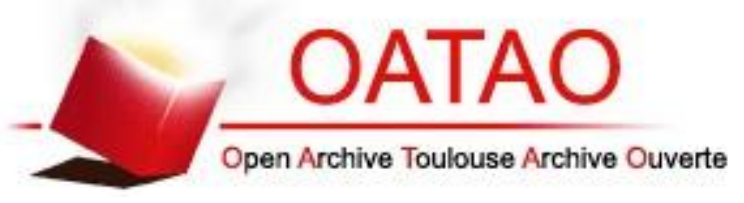

Open Archive Toulouse Archive Ouverte (OATAO)

OATAO is an open access repository that collects the work of Toulouse researchers and makes it freely available over the web where possible.

This is an author-deposited version published in: http://oatao.univ-toulouse.fr/ Eprints ID: 9902

Identification number: 10.1134/S1064229313090020

Official URL: http://dx.doi.org/10.1134/S1064229313090020

\section{To cite this version:}

Pampura, Tatiana and Probst, Anne and Ladonin, D.V. and Demkin, V.A. Lead content and isotopic composition in submound and recent soils of the Volga upland. (2013) Eurasian Soil Science, vol. 46 ( $\left.\mathrm{n}^{\circ} 11\right)$. pp. 1059-1075. ISSN $1064-2293$

Any correspondence concerning this service should be sent to the repository administrator: staff-oatao@inp-toulouse.fr 


\title{
SOIL CHEMISTRY
}

\section{Lead Content and Isotopic Composition in Submound and Recent Soils of the Volga Upland}

\author{
T. V. Pampura ${ }^{a}$, A. Probst ${ }^{b, c}$, D. V. Ladonin ${ }^{d}$, and V. A. Demkin ${ }^{a}$ \\ ${ }^{a}$ Institute of Physicochemical and Biological Problems of Soil Science, Russian Academy of Sciences, \\ ul. Institutskaya 2, Pushchino, Moscow oblast, 142290 Russia \\ E-mail: pampura@mail.ru \\ ${ }^{b}$ Université de Toulouse; INP, UPS; EcoLab (Laboratoire Ecologie Fonctionnelle et Environnement); \\ ENSAT, Avenue de l'Agrobiopôle, F-31326 Castanet-Tolosan, France \\ ${ }^{c}$ CNRS; EcoLab; F-31326 Castanet-Tolosan, France \\ ${ }^{d}$ Faculty of Soil Science, Moscow State University, Moscow, 119991 Russia
}

\begin{abstract}
Literature data on the historical reconstructions of the atmospheric lead deposition in Europe and the isotopic composition of the ores that are potential sources of the anthropogenic lead in the atmospheric deposition in the lower Volga steppes during different time periods have been compiled. The effect of the increasing anthropogenic lead deposition recorded since the Bronze Age on the level of soil contamination has been investigated. For the first time paleosol buried under a burial mound of the Bronze Age has been used as a reference point to assess of the current contamination level. The contents and isotopic compositions of the mobile and total lead have been determined in submound paleosols of different ages and their recent remote and roadside analogues. An increase in the content and fraction of the mobile lead and a shift of its isotopic composition toward less radiogenic values (typical for lead from the recent anthropogenic sources) has been revealed when going from a Bronze-Age paleosol to a recent soil. In the Bronze-Age soil, the isotopic composition of the mobile lead is inherited from the parent rock to a greater extent than in the modern soils, where the lead is enriched with the less radiogenic component. The effect of the anthropogenic component is traced in the analysis of the mobile lead, but it is barely visible for the total lead. An exception is provided by the recent roadside soils characterized by increased contents and the significantly less radiogenic isotopic composition of the mobile and total lead.
\end{abstract}

Keywords: soil lead, atmospheric lead fallout, stable lead isotopes, paleoecological reconstructions

DOI: $10.1134 / \mathrm{S} 1064229313090020$

\section{INTRODUCTION}

It is believed that the development of industry and the atmospheric transfer of heavy metals long distances resulted in the global contamination of the environment with lead $(\mathrm{Pb})$ and that the metal content in the recent soils and bottom sediments is determined by the 3500- to 4000-year-long history of the anthropogenic impact $[8,51,52,66]$. For historical reconstructions of the atmospheric lead deposition, "the natural archives" are studied, including stratified bottom sediments $[19,32,52]$, peat deposits $[8,32,37$, $39,60,61,66]$, and glaciers [10, 26, 44, 53, 65]. However, the quantification of the scope of the current contamination of the soil cover requires a reference point: uncontaminated preindustrial soils.

"The anthropogenic archives," i.e., paleosols buried under old mounds or fortified structures, are widely used in archeological soil science for paleoclimatic reconstructions $[1-3,14,31]$. An analogous approach appears to be also promising for historical reconstructions of the soil contamination with heavy metals. In this case, paleosols buried under mounds at the dawn of human society could serve as background soils for the assessment of the current contamination level.

However, there also is an opinion that soils can hardly be used as such archives because of the possible migration, redistribution, and removal of metals beyond the soil profile [66]. Nonetheless, the soillandscape and climatic conditions in the dry- and desert-steppe zones (small precipitation, high $\mathrm{pH}$ values, and the presence of carbonates in the soil) are favorable for the immobilization of lead and hamper its leaching from the soil. This should favor the conservation of the soil features developed under the paleoecological conditions of the time of the soil burial.

The main aim of our study was to elucidate whether the anthropogenic impact during the last 3500 years significantly affected the concentrations, chemical forms, and isotopic composition of the lead in the drysteppe soils of the Low Volga region. Our work was based on the comparative analysis of submound chestnut paleosols of the Bronze and early Iron Ages and 
their modern background analogues located in the vicinity of the burial mound and in the roadside soils at different distances from a road.

\section{USE OF STABLE LEAD ISOTOPES IN GEOCHEMISTRY AND ENVIRONMENTAL SCIENCE}

Since the 1930s, the stable lead isotopes have been used in geochronology for establishing the age of minerals, ores, and Solar System objects $[4,6]$, as well as in archeology for determining the origin of metal artifacts $[36,56]$. Later on, as the methods of isotope analysis were developed and simplified and the danger of uncontrolled environmental contamination was recognized, the isotope analysis of lead found successful use in environmental science for the historical reconstruction of the atmospheric lead deposition and the tracing of its sources. A large number of publications are devoted to this issue; unfortunately, most of them have been issued beyond Russia. The most complete reviews of the literature are presented by Komárek et al. [34] and Weiss et al. [66].

The main principles of the isotope geochemistry of lead are published in the literature $[4,6]$. Four stable lead isotopes are known (the tabulated abundance of the isotopes in nature is shown in parentheses): ${ }^{204} \mathrm{~Pb}$ (1.4\%), ${ }^{206} \mathrm{~Pb}(24.1 \%),{ }^{207} \mathrm{~Pb}(22.1 \%),{ }^{208} \mathrm{~Pb}(52.4 \%)$ [54]. Among the four lead isotopes, only ${ }^{204} \mathrm{~Pb}$ is not radiogenic; the ${ }^{206} \mathrm{~Pb}$ isotope is the final product of the radioactive decay of ${ }^{238} \mathrm{U}$ with a halftime $\left(\mathrm{T}_{1 / 2}\right)$ of $4.47 \times 10^{9}$ years; ${ }^{207} \mathrm{~Pb}$ is the product of decay of ${ }^{235} \mathrm{U}$ $\left(\mathrm{T}_{1 / 2}=7.0 \times 10^{8}\right.$ years $)$, and ${ }^{208} \mathrm{~Pb}$ results from the decay of ${ }^{232} \mathrm{Th}\left(\mathrm{T}_{1 / 2} 1.4 \times 10^{10}\right.$ years $)$. The content of ${ }^{204} \mathrm{~Pb}$ in an object (rock, mineral) remains constant in time, while the contents of the radiogenic isotopes increase with different rates because of the radioactive decay of the mother radionuclides. The isotope ratio is thus determined by the initial proportions of $\mathrm{Pb}, \mathrm{U}$, and $\mathrm{Th}$ and the time of their coexistence. The $\mathrm{U} / \mathrm{Th}, \mathrm{U} / \mathrm{Pb}$, and $\mathrm{Th} / \mathrm{Pb}$ ratios change during the evolution of the Earth and the formation and fractionation of magma under the effects of metamorphism, hydrothermal processes, and weathering. The most radiogenic lead (enriched with the ${ }^{206} \mathrm{~Pb},{ }^{207} \mathrm{~Pb}$, and ${ }^{208} \mathrm{~Pb}$ isotopes forming and accumulating due to the radioactive decay of $U$ and $T h$ ) is present in old $U$ - and Th-containing minerals (e.g., uraninite, thorite, monazite, zircon, etc.). A less radiogenic composition is typical for the lead of minerals with low $\mathrm{U} / \mathrm{Pb}$ and $\mathrm{Th} / \mathrm{Pb}$ ratios (e.g., galena $\mathrm{PbS}$ or $\mathrm{K}$-feldspar in which $\mathrm{Pb}^{2+}$ isomorphically substitutes for $\mathrm{K}^{+}$), in which the isotope composition of $\mathrm{Pb}$ has almost not changed since the time of the minerals' crystallization. The most radiogenic lead usually occurs in accessory minerals; therefore, the isotope ratios of the rock are much closer to the composition of the lead in plagioclases and $\mathrm{K}$-feldspars than to that of the radiogenic lead in the accessory minerals. The least radiogenic composi- tion is found in troilite $(\mathrm{FeS})$ minerals, which contain almost no $\mathrm{U}$ and $\mathrm{Th}$. It is believed that meteorites were formed simultaneously with the Earth $4.55-4.57$ billion years ago [4] from an isotopically homogeneous matter. The isotope composition of the lead in the iron meteorite from the Diable Canyon [63] has been taken as the original composition of the lead in the Earth: ${ }^{206} \mathrm{~Pb} /{ }^{204} \mathrm{~Pb} 9.307,{ }^{207} \mathrm{~Pb} /{ }^{204} \mathrm{~Pb} 10.294,{ }^{208} \mathrm{~Pb} /{ }^{204} \mathrm{~Pb}$ 29.476. According to the popular model of Stacy and Kramers [62], the isotope composition of the lead in the Earth's crust has varied since the formation of the Earth due to the decay of $\mathrm{U}$ and $\mathrm{Th}$ from the original composition of the primitive $\mathrm{Pb}$ toward a more radiogenic composition up to the current mean-crust $\mathrm{Pb}$ : ${ }^{206} \mathrm{~Pb} /{ }^{204} \mathrm{~Pb} 18.7,{ }^{207} \mathrm{~Pb} /{ }^{204} \mathrm{~Pb} \quad 15.628,{ }^{208} \mathrm{~Pb} /{ }^{204} \mathrm{~Pb}$ 38.63. The latter was obtained from the mean isotopic compositions of the $\mathrm{Pb}$ in sedimentary and volcanic rocks and the $\mathrm{Pb}+\mathrm{Pb}$ isochrones of modern granite rocks [62]. Later on the isotope composition of the crust lead was specified [7, 25, 35, 40]. The graphic representation of the progressive changes in the isotope composition with time is called the growth curve. The Stacy-Kramers model suggests that the lead evolved in a homogeneous reservoir with specific initial parameters $\left(\mu={ }^{238} \mathrm{U} /{ }^{204} \mathrm{~Pb}\right.$ and $\left.\omega={ }^{232} \mathrm{Th} /{ }^{204} \mathrm{~Pb}\right)$ during the second formation stage of the Earth's crust, i.e., during the last 3.7 billion years. In fact, the Earth is chemically heterogeneous, and the evolution of the lead is rather described by a set of growth curves related to different reservoirs with different parameters $\mu$ and $\omega$.

At a specific evolution stage of a mantle or crust reservoir, the separation of the ore lead occurs because of the geological processes. The isotope composition of galena $\mathrm{PbS}$, the main ore mineral of lead, remains almost unchanged after its formation because of the low contents of $U$ and $T h$. The primary variations of the rock's isotope composition depend on the rock's age: older ores have less radiogenic compositions than younger ores. The composition variations of the second order are related to the chemical composition and age of the primary reservoir (the source of lead in the ore deposit). The ores of the same age, in which lead originated from the reservoirs evolving along different growth curves (with different $\mu$ and $\omega$ ), will have different isotope compositions [55]. The situation becomes even more complicated for the composition of lead after its separation from the reservoir because of the mixing with lead from other sources during transportation or due to the co-existence with U- and Th-minerals after the formation of the ore [4]. As a result, the proportions of lead isotopes in ores reflecting the complex geological history of their formation vary in a wide range and are often sufficiently specific to serve as fingerprints of a given deposit.

Thus, the isotopic composition of the minerals, rocks, and ores can vary significantly; they are mainly determined by the time of their formation and the initial $\mathrm{U} / \mathrm{Pb}$ and $\mathrm{Th} / \mathrm{Pb}$ ratios. Old crystalline Precam- 
brian rocks with high initial $\mathrm{U} / \mathrm{Pb}$ and $\mathrm{Th} / \mathrm{Pb}$ ratios, which compose Fennoscandia and Canada, are characterized by more radiogenic lead isotopic compositions $\left({ }^{206} \mathrm{~Pb} /{ }^{207} \mathrm{~Pb}=1.3-2.0\right)$ than, e.g., the Atlantic marine sediments and the sedimentary rocks and soils of the main part of Europe $\left({ }^{206} \mathrm{~Pb} /{ }^{207} \mathrm{~Pb} \sim 1.2\right)$ [9]. Old Precambrian ores (e.g., the known Broken Hill deposit in Australia, which is the main source of lead in Western Europe for the production of antiknock additives) are characterized by low values $\left({ }^{206} \mathrm{~Pb} /{ }^{207} \mathrm{~Pb} \sim 1.04\right)$ because of the early separation of $\mathrm{Pb}$ from $\mathrm{U}$ and $\mathrm{Th}$ due to the crystallization of ore minerals [55]. The younger ores and coal $(<500$ million years) used in Europe during the preindustrial period have higher ${ }^{206} \mathrm{~Pb} /{ }^{207} \mathrm{~Pb}$ ratios $(1.16-1.18)$ [9].

It is known that different terms, analytical methods, and presentations of the result are used in geochemistry and environmental sciences [55]. In isotope geochronology, the isotope composition of lead is expressed by the ratio of the radiogenic isotopes to the nonradiogenic isotope, whose amount does not change with time: ${ }^{206} \mathrm{~Pb} /{ }^{204} \mathrm{~Pb},{ }^{207} \mathrm{~Pb} /{ }^{204} \mathrm{~Pb}$, and ${ }^{208} \mathrm{~Pb} /{ }^{204} \mathrm{~Pb}$. However, Cumming and Richards [12] proposed a geochronological model using the ${ }^{207} \mathrm{~Pb} /{ }^{206} \mathrm{~Pb}$ ratio, which linearly decreases with time. This ratio (more exactly, the inverse ${ }^{206} \mathrm{~Pb} /{ }^{207} \mathrm{~Pb}$ ratio) is most frequently used in environmental sciences. The analysis of the temporal evolution of the ${ }^{207} \mathrm{~Pb} /{ }^{206} \mathrm{~Pb}$ and ${ }^{208} \mathrm{~Pb} /{ }^{206} \mathrm{~Pb}$ ratios within the framework of the Stacy-Kramers model [62] also indicates a monotonic decrease of these isotope ratios with time during the last 3.7 billion years and the possibility of their use for dating rocks and ores. In this case, the more radiogenic compositions are characterized by lower ${ }^{207} \mathrm{~Pb} /{ }^{206} \mathrm{~Pb}$ and ${ }^{208} \mathrm{~Pb} /{ }^{206} \mathrm{~Pb}$ ratios.

In isotope geochemistry, one mainly uses more laborious but more accurate methods of isotope analysis: thermal-ionization mass spectrometry (TIMS) and multicollector inductively coupled plasma mass spectrometry (MC-ICP-MS). The wide use of isotope analysis in environmental sciences became possible with the development of more available and rapid but less precise instruments based on inductively coupled plasma quadrupole mass spectrometry (ICP-QMS). Unfortunately, these instruments determine the isotope composition with an accuracy of $0.2-2 \%$ (RSD), while TIMS and MC-ICP-MS can reach an accuracy of $0.001-0.002 \%$ [37]. The accuracy of ICP-QMS is insufficient for the reliable determination of the least abundant ${ }^{204} \mathrm{~Pb}$ isotope. As a result, most authors do not take ${ }^{204} \mathrm{~Pb}$ into account and most frequently use the ${ }^{206} \mathrm{~Pb} /{ }^{207} \mathrm{~Pb}$ ratio. Results are also often presented in the coordinates ${ }^{208} \mathrm{~Pb} /{ }^{206} \mathrm{~Pb}$ vs. ${ }^{206} \mathrm{~Pb} /{ }^{207} \mathrm{~Pb}$, ${ }^{207} \mathrm{~Pb} /{ }^{206} \mathrm{~Pb}$ vs. ${ }^{208} \mathrm{~Pb} /{ }^{206} \mathrm{~Pb}$, or ${ }^{208} \mathrm{~Pb} /{ }^{207} \mathrm{~Pb}$ vs. ${ }^{206} \mathrm{~Pb} /{ }^{208} \mathrm{~Pb}$. When ${ }^{204} \mathrm{~Pb}$ is ignored, the probability of the correct determination of the $\mathrm{Pb}$ source obviously decreases; however, according to [55], it remains sufficiently high and correctly characterizes the ore source in $86 \%$ of the cases.

\section{ANTHROPOGENIC LEAD IN ATMOSPHERIC DEPOSITION}

The specific composition of ore- $\mathrm{Pb}$ allows one to distinguish between the "natural" lead of the local rocks and soils and the anthropogenic lead deposited by atmospheric fallout. In some case, it is possible to trace the sources of anthropogenic lead.

Over the almost 5000-year-long history of metallurgy, ore lead has been extracted onto the surface and involved in global biogeochemical cycles at an increasing scale. In the period between 4000 and 2700 years ago, the annual production of the metal was $160 \mathrm{t}$ [58]. During the rise of the Roman Empire (about 2000 years ago), it increased to $80000 \mathrm{t} /$ year; after some decrease in the Middle Ages, it reached 100000 t/year at the beginning of the industrial revolution about 300 years ago and abruptly rose to 1 million $\mathrm{t} / \mathrm{year}$ in the first half of the 20th century [58]. In 1997, about $3.04 \times 10^{6} \mathrm{t}$ of lead was produced in the world [29] (Fig. 1). Due to the emission of ore lead in Europe over the last 30004000 years, the isotopic composition of the atmospheric deposition gradually changed from more radiogenic, similar to the composition of the upper earth's crust, to less radiogenic caused by the presence of less radiogenic European ore lead, which was recorded in numerous natural "archives" such as sea and lake bottom sediments, peat and ice cores $[9,34$, 66]. The evolution of the isotope composition of the atmospheric lead deposition and the history of the global lead production are shown in Fig. 1. Our generalization of the literature data on the changes in the ${ }^{207} \mathrm{~Pb} /{ }^{206} \mathrm{~Pb}$ and ${ }^{206} \mathrm{~Pb} /{ }^{208} \mathrm{~Pb}$ ratios in the ombrotrophic (rain fed) peat cores of Europe from Spain to Sweden is given in the top of the figure. The scattering of the isotopic ratios decreases with time, and they shift toward less radiogenic values; the current temporal trends in the composition of the atmospheric deposition well agree with the evolution of the global lead production [58] (Fig. 1). Peaks corresponding to the maximum production in the times of Ancient Greece and Rome, in the Middle Ages (the production of silver in Germany), and during the period of the industrial revolution and the development of industry and motor transport in the early 20th century are noted in many individual profiles (even in Northern Europe removed from the metallurgy of the ancient world). The predominance of ore lead of anthropogenic origin can be the reason that the isotopic composition of its current atmospheric deposition has become significantly less radiogenic compared to the preindustrial period and is characterized by lower variability. At the same time, it should be noted that the mechanical assignment of the meaning of the anthropogenic signal to specific isotope ratios would be improper. The presence of less radiogenic lead (originating from natural sources) in the atmospheric deposition is confirmed by peaks along the evolution curves of the peat's isotopic composition in the interval from 6000 to 4000 years ago, when there was no question of serious anthropo- 

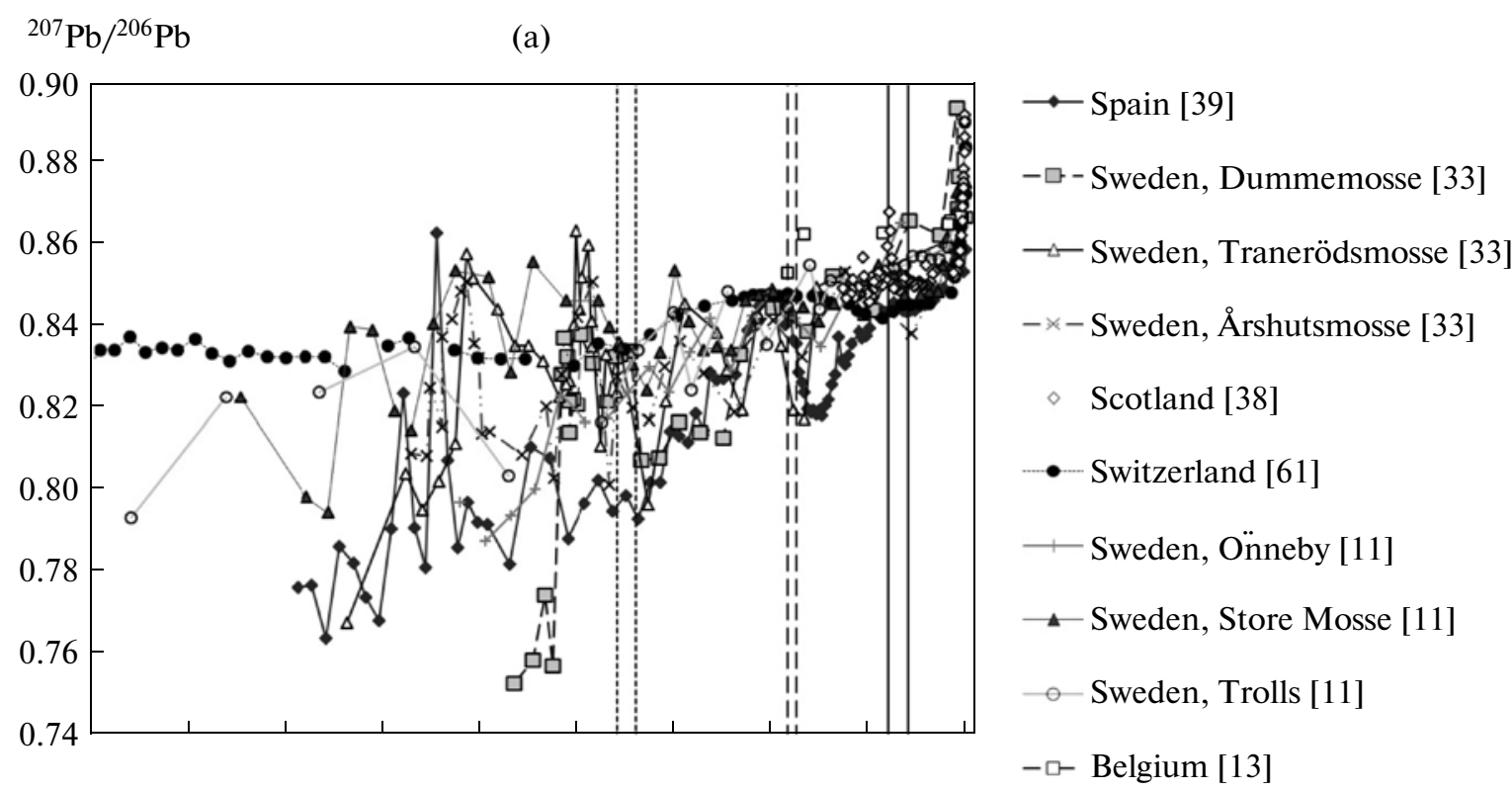

${ }^{208} \mathrm{~Pb} /{ }^{206} \mathrm{~Pb}$

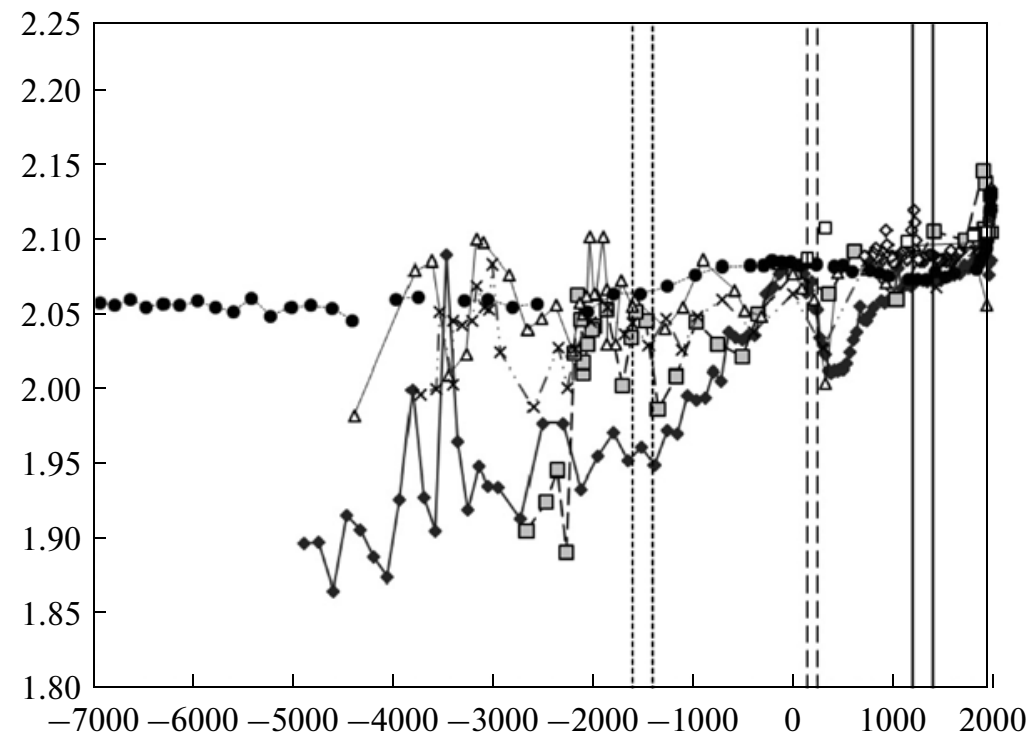

(b)

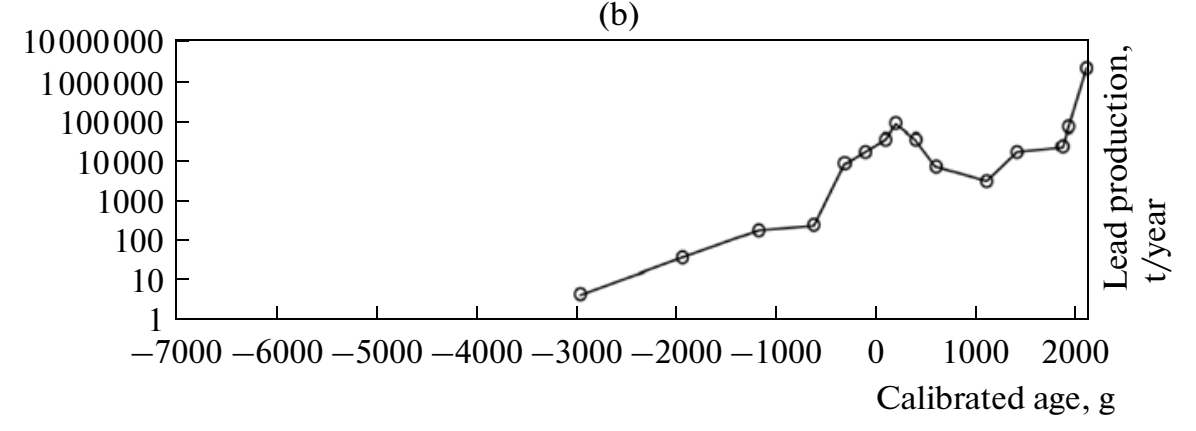

Fig. 1. Changes in the lead isotope ratios in the dated European peat cores. The vertical lines indicate the time intervals of the Bronze and early Iron Ages corresponding to the burial of the studied submound soils and those of the 13th-14th centuries AD used for plotting the composition of the atmospheric deposition as a function of the time: (a) ${ }^{207} \mathrm{~Pb} /{ }^{206} \mathrm{~Pb}$ and ${ }^{208} \mathrm{~Pb} /{ }^{206} \mathrm{~Pb}$. (b) History of the global lead production [58]. 
Table 1. Lead emission from natural and anthropogenic sources [46-49]

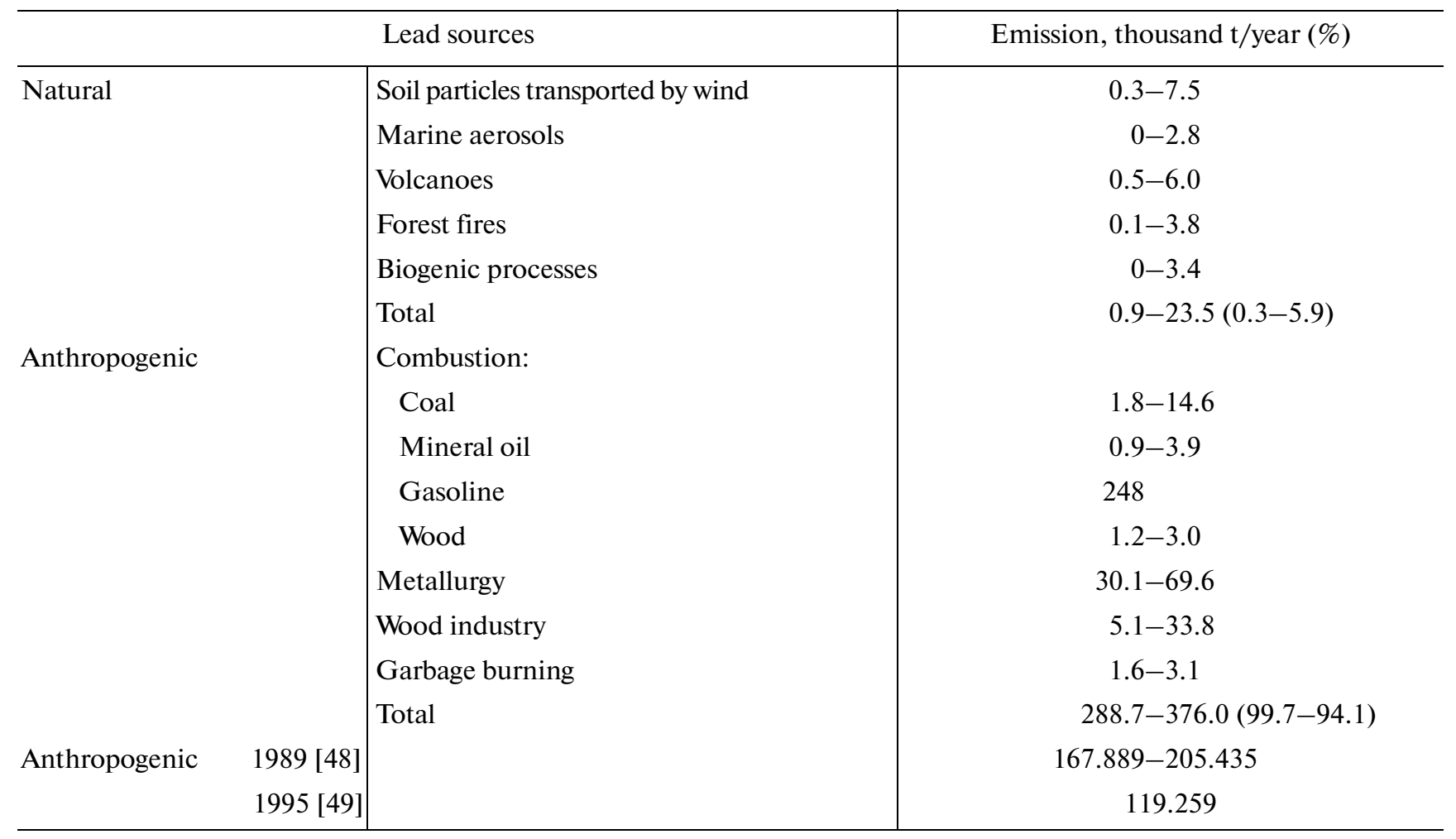

genic impact. Similar maximums are noted in peat cores from the opposite corners of Europe (Spain and Sweden), and the ${ }^{207} \mathrm{~Pb} /{ }^{206} \mathrm{~Pb}$ and ${ }^{208} \mathrm{~Pb} /{ }^{206} \mathrm{~Pb}$ ratios were even higher than those in the peat layers corresponding to the Roman Empire period: ${ }^{207} \mathrm{~Pb} /{ }^{206} \mathrm{~Pb}$ 0.850 (or ${ }^{206} \mathrm{~Pb} /{ }^{207} \mathrm{~Pb}=1.176$ ) and ${ }^{208} \mathrm{~Pb} /{ }^{206} \mathrm{~Pb}=$ 2.090. Kylander et al. [37] noted that, although ${ }^{207} \mathrm{~Pb} /{ }^{206} \mathrm{~Pb} \leq 0.84\left({ }^{206} \mathrm{~Pb} /{ }^{207} \mathrm{~Pb} \geq 1.19\right)$ for most of the natural sources of atmospheric lead, the emissions from the volcanoes of the Northern Atlantic (the Faroe Islands), in whose rocks ${ }^{207} \mathrm{~Pb} /{ }^{206} \mathrm{~Pb}$ ratio is equal to $0.86\left({ }^{206} \mathrm{~Pb} /{ }^{207} \mathrm{~Pb} 1.16\right)$ [64], can be sources of less radiogenic lead in these cases.

In the 1980s, gasoline was the main source of anthropogenic lead in the atmosphere [46-49] (Table 1). Since then, the global situation with atmospheric fallout has slightly improved due to the prohibition of the use of tetraethyl lead as an antiknock additive to gasoline. However, the consequences for the soil cover will not be soon significant because of the low mobility of lead in the soil.

Ideally, a database on the isotope composition of the lead from anthropogenic and natural sources should be created for assessing the scope of the anthropogenic impact and characterizing the roles of the individual sources. There is still no such database, but information on the isotope composition of the lead from different natural sources was given in the paper of Kylander et al. [37]. Lead isotope ratios were also reported for the main ore deposits in Europe and
North America, gasoline, and some other individual sources [15, 27, 34, 42, 43, 55]. Although they are far from being always specific, they are frequently sufficiently contrasting with the local geochemical background and allow determining the source and scale of the anthropogenic global impact $[17,18,20,21,23$, $38,41,43,45,59]$. Studies on the lead isotopic composition in recent soils are reviewed by Komárek et al. [34] and Weiss et al. [66]. A recent publication of the map of $\mathrm{Pb}$ contents and isotope ratios in the top horizons (Ap, $0-20 \mathrm{~cm}$ ) of agricultural soils in the major part of Europe at a density of 1 sample per $2500 \mathrm{~km}^{2}$ (except for the territory of Russia) also contributed significantly [50]. The map shows a wide scattering in the contents $(1.6-1309 \mathrm{mg} / \mathrm{kg}$, median $16 \mathrm{mg} / \mathrm{kg}$ ) and isotope ratios of the lead in European soils $\left({ }^{206} \mathrm{~Pb} /{ }^{207} \mathrm{~Pb}=1.116-1.727\right.$, median 1.202; ${ }^{208} \mathrm{~Pb} /{ }^{206} \mathrm{~Pb}=1.477-2.702$, median 2.067$)$. A significant difference in the content and isotope composition of the lead was revealed between Northern and Southern Europe with higher concentrations and a less radiogenic isotopic composition being observed in the south. In the opinion of the map's authors, which largely contradicts most of the recent publications, the spatial distribution and isotopic composition of the lead are controlled by the geological (the age and chemical composition of the rocks, the presence of ore anomalies) and climatic (the weathering processes, the last glaciation's boundaries) factors rather than by the anthropogenic factors on the continental scale. 
However, separate local anthropogenic anomalies undoubtedly exist [50].

\section{REGION, OBJECTS, AND METHODS OF STUDY}

The region of study is located in the dry steppe zone of the southern Volga Upland. The climate is moderately continental. The mean annual precipitation is about $400 \mathrm{~mm}$. The current soil cover consists of a combination of chestnut soils with different degrees of solonetzization and salinization and solonetzs.

The objects of the study were the buried and recent chestnut soils of the Salomatino burial mound located $5 \mathrm{~km}$ to the north of the village of Salomatino in the Kamyshin raion of Volgograd oblast. The excavations of the monuments were performed by the archeological expedition of Volgograd State University led by I.V. Sergatskov. The sampling site is located on the flat edge of the Ilovlya and B. Kazahka interfluve on the high right bank of the Ilovlya River. The area is slightly inclined toward the river valley with an inclination of $5 \mathrm{~m} / \mathrm{km}$. The absolute height marks are $170-150 \mathrm{~m}$. The area is composed of binary deposits to a depth of $2 \mathrm{~m}$ : covering loess-like sandy loams occur from the surface to a depth of 50-60 cm underlain by ferruginized gleyed diluvial loamy sandy-loamy deposits with inclusions of pebbles and gravel. The groundwater occurs deeper than $20 \mathrm{~m}$. The soil is virgin. In the plant cover, herb-fescue-stipa (chestnut soils) and wormseed-fescue (solonetzs) associations with projective covers of 90 and $50 \%$, respectively, are predominant.

Submound chestnut paleosols of two monuments, the construction of which dates from the late Bronze (the Srubnaya culture, the 16th-15th centuries BC, $\sim 3500$ years ago) and early Iron (the late Sarmatian culture, the second half of the 2nd century-the first half of the 3rd century AD, 1800 years ago) ages, were studied, as well as their recent background analogues.

In the samples of the soils taken from the genetic horizons, the conventional chemical analyses were performed (for the humus, soluble salts, gypsum, carbonates, the particle-size distribution, etc.), and the content and isotopic composition of the mobile and total lead were determined. To analyze the characteristic features of the isotopic composition of the lead from the local anthropogenic sources (motor transport), soil samples were taken from the A1 horizon in the close vicinity $(2,5$, and $10 \mathrm{~m})$ of the local dirt road and the Volgograd-Moscow motorway $(\mathrm{km} \mathrm{39,}$ $48^{\circ} 30^{\prime} \mathrm{N}, 44^{\circ} 10^{\prime} \mathrm{E}$ ).

The extraction of the lead and the following analysis were performed in duplicate for an average sample taken from each genetic horizon. To determine the bulk composition, the soil was decomposed in an $\mathrm{HF}-$ $\mathrm{HNO}_{3}$ mixture at $90^{\circ} \mathrm{C}$, and the organic matter was then removed by treatment with $\mathrm{H}_{2} \mathrm{O}_{2}+\mathrm{HNO}_{3}$. All the operations were performed under superclean conditions (using a clean room in the Laboratoire des mécanismes et transferts en géologie (LMTG) (CNRS/University of Toulouse-III/IRD/OMP) Toulouse, France). The mobile lead was extracted with a 1 $\mathrm{M}$ ammonium acetate buffer solution at $\mathrm{pH} 4.8$ with a soil : solution ratio of $1: 10$. The concentrations of the main elements, metals, and rare elements were determined by ICP-OES and ICP-QMS (using a PerkinElmer ELAN 6000 and an ICP-MS Agilent 7500A, respectively). The isotopic composition of the lead was determined using an ICP-MS Agilent 7500A instrument (the total form was analyzed in the LMTG in Toulouse; the mobile form was analyzed at the Faculty of Soil Science of Moscow State University). The NBS 981 standard was used for the correction of the drift and the systematic error. The mean relative standard deviations in the determination of the isotope ratios were $0.23 \%$ for ${ }^{207} \mathrm{~Pb} /{ }^{206} \mathrm{~Pb}$ and $0.22 \%$ for ${ }^{208} \mathrm{~Pb} /{ }^{206} \mathrm{~Pb}$ for the total form (37 determinations) and $0.93 \%$ for ${ }^{207} \mathrm{~Pb} /{ }^{206} \mathrm{~Pb}$ and $1.01 \%$ for ${ }^{208} \mathrm{~Pb} /{ }^{206} \mathrm{~Pb}$ for the mobile form (70 determinations).

\section{RESULTS AND DISCUSSION}

The main chemical characteristics of the submound and recent soils are given in Table 2 . The paleosol of the late Bronze Age (16th-15th centuries BC, the Srubnaya culture) belongs to nonsolonetzic solonchakous chestnut soils. It is buried under a mound $50 \mathrm{~cm}$ in height and about $20 \mathrm{~m}$ in diameter. The particle-size distribution of the soil-sediment layer is nonuniform; its texture varies from loamy sandy to loamy. The content of the clay fraction $(<0.001 \mathrm{~mm})$ varies throughout the profile in a relatively narrow range from 11 to $18 \%$. The depth of the humus layer $(\mathrm{A} 1+\mathrm{B} 1)$ is low; it is $24 \mathrm{~cm}$. The content of humus in the A and B1 horizons was estimated at 0.75 and $0.60 \%$, respectively. Effervescence is observed from a depth of $12 \mathrm{~cm}$. The content of carbonates does not exceed $4 \%$ in the zone of accumulation. Their neoformations consist of fine veins, incrustations, and impregnations. Veins of soluble salts and gypsum occur from a depth of $35 \mathrm{~cm}$; their content in the zone of accumulation (the Dca,s,g horizon) is relatively low (less than $0.5 \%$ ). The salinity of the layer is of sodium sulfate type. It should be noted that the concentration of chloride ions in the water extract is insignificant (no more than $0.1 \mathrm{meq} / 100 \mathrm{~g}$ ) throughout the profile. The $\mathrm{pH}$ value varies from 8.3 to 8.8 .

The paleosol of the late Iron Age (second half of the 2nd century-first half of the 3rd century AD, late Sarmatian culture) belongs to solonetzic solonchakous chestnut soils. The mound is about $60 \mathrm{~cm}$ high and $20 \mathrm{~m}$ in diameter. The texture of the paleosol is sandy loamy (A1 horizon) and loamy (B1 and B2ca horizons); the underlying rock is sandy loamy in texture. The content of physical clay in the solonetzic horizon does not exceed $40 \%$. The depth of the humus layer $(\mathrm{A} 1+\mathrm{B} 1)$ is $33 \mathrm{~cm}$. The remaining content of humus 
Table 2. Chemical properties of submound and recent soils

\begin{tabular}{|c|c|c|c|c|c|c|c|}
\hline \multirow{2}{*}{$\begin{array}{l}\text { Horizon, } \\
\text { depth, cm }\end{array}$} & \multirow{2}{*}{ Humus, \% } & \multirow{2}{*}{$\mathrm{pH}_{\mathrm{H}_{2} \mathrm{O}}$} & Total salts & $\mathrm{CaCO}_{3}$ & $\mathrm{CaSO}_{4}$ & \multicolumn{2}{|c|}{ Fractions, \% } \\
\hline & & & \multicolumn{3}{|c|}{$\%$} & $<0.001 \mathrm{~mm}$ & $<0.01 \mathrm{~mm}$ \\
\hline \multicolumn{8}{|c|}{ Nonsolonetzic solonchakous chestnut paleosol, 16th-15th centuries BC } \\
\hline A1mound, $0-15$ & 2.12 & 7.4 & 0.06 & 0.0 & 0.01 & 16 & 30 \\
\hline Bmound, 15-46 & 1.05 & 8.2 & 0.08 & 1.7 & 0.02 & 11 & 29 \\
\hline A1, 46-57 & 0.75 & 8.3 & 0.07 & 1.8 & 0.01 & 14 & 29 \\
\hline B1ca, 57-70 & 0.60 & 8.7 & 0.09 & 3.0 & 0.01 & 18 & 34 \\
\hline B2, 70-80 & 0.22 & 8.8 & 0.06 & 1.5 & 0.01 & 11 & 18 \\
\hline Dca,s,g 80-150 & nd & 8.4 & 0.34 & 3.6 & 0.46 & 14 & 25 \\
\hline \multicolumn{8}{|c|}{ Solonetzic solonchakous chestnut paleosol, 2nd-3rd centuries AD } \\
\hline Almound, $0-10$ & 2.12 & 7.3 & 0.03 & 0.0 & 0.00 & 12 & 23 \\
\hline Bmound, 10-55 & 1.41 & 7.7 & 0.03 & 1.1 & 0.00 & 17 & 32 \\
\hline$A 1,55-67$ & 1.51 & 8.7 & 0.06 & 1.6 & 0.00 & 10 & 26 \\
\hline B1, 67-88 & 1.10 & 9.1 & 0.08 & 1.5 & 0.00 & 25 & 42 \\
\hline B2ca, 88-102 & 0.84 & 9.3 & 0.10 & 12.4 & 0.04 & 24 & 39 \\
\hline D1ca, $102-147$ & nd & 8.5 & 0.39 & 7.4 & 0.25 & 14 & 23 \\
\hline D2, 147-180 & $"$ & 8.4 & 0.27 & 1.6 & 0.13 & 14 & 26 \\
\hline D3, $180-250$ & $"$ & 8.2 & 0.13 & 0.4 & 0.03 & 11 & 28 \\
\hline \multicolumn{8}{|c|}{ Deeply saline nonsolonetzic recent chestnut soil } \\
\hline Ad, $0-11$ & 2.77 & 6.7 & 0.05 & 0.0 & 0.00 & 8 & 26 \\
\hline A1, $11-30$ & 1.37 & 6.5 & 0.02 & 0.0 & 0.00 & 13 & 28 \\
\hline B1, 30-53 & 1.10 & 7.3 & 0.04 & 0.0 & 0.00 & 31 & 40 \\
\hline B2, 53-65 & 0.76 & 8.2 & 0.05 & 0.9 & 0.00 & 18 & 27 \\
\hline Dca, 65-170 & nd & 8.2 & 0.33 & 12.5 & 0.00 & 16 & 28 \\
\hline
\end{tabular}

in the A and B1 horizons is 1.51 and $1.10 \%$, respectively. Effervescence is observed from a depth of $33 \mathrm{~cm}$. The content of carbonates in the zone of accumulation (B2ca horizon) exceeds $12 \%$. Their neoformations consist of incrustations and mealy forms (D1ca horizon). Veins of soluble salts and gypsum occur from a depth of 47 and $50 \mathrm{~cm}$, respectively, with the maximum contents in the D1ca horizon. The salinity of the underlying rock (deeper than $50 \mathrm{~cm}$ ) varies from the sodium sulfate to the sodium sulfatechlorite type. Chlorides are the predominant anions in the 1- to 2-m layer of the profile; their concentration reaches $2.5 \mathrm{meq} / 100 \mathrm{~g}$. The soil reaction is alkaline throughout the profile. The maximum $\mathrm{pH}$ values (9.1-9.3) are found in the B1 and B2ca horizons.

The recent background soil was studied in the center of the mound group on a virgin plot with an herbfescue-stipa association. The projective cover of the vegetation is $90 \%$. This is a deeply saline nonsolonetzic chestnut soil. It is predominantly sandy loamy in texture. Only the illuvial B1 horizon is loamy with a high clay content (more than $30 \%$ ). The depth of the humus layer $(\mathrm{Ad}+\mathrm{A} 1+\mathrm{B} 1)$ is $53 \mathrm{~cm}$. The content of humus is about $3 \%$ in the Ad horizon and abruptly decreases with depth (by two times in the A1 horizon). The $65-\mathrm{cm}$ thick soil layer is leached from carbonates and soluble salts. Gypsum is absent throughout the studied profile $(170 \mathrm{~cm})$. Effervescence is noted from a depth of $65 \mathrm{~cm}$. The main stock of carbonates is concentrated in the underlying rock (Dca horizon), where the content of $\mathrm{CaCO}_{3}$ exceeds $12 \%$. Here, the highest content of soluble salts (more than $0.3 \%$ ) is observed; their rare veins are recorded from a depth of $150 \mathrm{~cm}$. The salinity of this layer is of sodium sulfate type; the concentration of chlorides in the water extract is insignificant and does not exceed $0.2 \mathrm{meq} / 100 \mathrm{~g}$. The soil reaction is neutral ( $\mathrm{pH}$ 6.5-7.3) in the upper horizons and alkaline $(\mathrm{pH} 8.2)$ in the deeper horizons.

Reconstruction of the atmospheric lead deposition. According to the European Monitoring and Evaluation Program (EMEP), the current atmospheric lead deposition in the studied region is relatively low com- 
pared to Europe: it is $0.5-1 \mathrm{~kg} / \mathrm{km}^{2}$ per year [28]. In the most part of Europe, the lead deposition varies from 0.4 to $2 \mathrm{~kg} / \mathrm{km}^{2}$ per year with the highest values observed in Poland, northern Italy, and the countries of the Benelux and Balkan region $\left(>3 \mathrm{~kg} / \mathrm{km}^{2}\right.$ per year). The lowest deposition is observed in northern Russia and Scandinavia. Unfortunately, no data are available on the isotopic composition of the lead deposition in the studied region in the past or present time. However, taking into consideration the global character of the atmospheric lead transport, we can estimate the level of deposition in specific time intervals in the past from the averaged European data, which we compiled and presented in Fig. 1. The isotopic composition of the current deposition can be approximated the mean composition of the Russian aerosols.

From the data of the European peat archives (Fig. 1), the composition of the atmospheric deposition for several time intervals (the Bronze Age, 3600-3400 years ago; the early Iron Age, 1850-1750 years ago; the Middle Ages, 800-600 years ago; and the post-WWII period, 1949-2003) are shown in the coordinates ${ }^{207} \mathrm{~Pb} /{ }^{206} \mathrm{~Pb}$ vs. ${ }^{208} \mathrm{~Pb} /{ }^{206} \mathrm{~Pb}$ in Fig. $2 \mathrm{a}$, as well as the lead composition of the Russian gasoline and the modern Russian aerosols according to Mukai et al. [43]. The dotted lines indicate the variation range of the lead isotopic composition in the upper Earth's crust [7, 25, 35, 40], which is often used to characterize the lead of natural origin. The composition of the atmospheric lead deposition changed in time from more radiogenic levels, which are close to that of the lead of the upper Earth's crust, to less radiogenic ones close to that of the lead in the Russian gasoline and aerosols. Apparently, the lead from natural sources prevailed in the atmospheric deposition in the Bronze Age, while the anthropogenic ore-lead is predominant in the current atmospheric deposition.

However, the evolution of the lead isotopic composition in the atmospheric deposition probably took place not only under the effect of an increasing portion of ore-lead but also due to the changes in the metal sources and the ores' composition. The isotope compositions of the lead and lead-containing ores of the Bronze and Antique Ages [36, 56, 57] as potential sources of anthropogenic lead in the atmospheric deposition of the studied region in the Bronze and early Iron Ages are shown in Fig. 2b. The compositions of the modern lead ores of Russia and the former USSR countries [15, 22, 43], whose lead could have been used recently for the production of antiknock additives for Russian motor fuels, are also shown. For comparison, the variation range of the lead's composition in the upper continental Earth's crust [7, 25, 35, 40] and the underlying rocks of the studied region (the D horizons of the studied soil profiles) is shown by the dotted lines. The solid line denotes the growth curve presenting the evolution of the isotopic composition of the
Earth' crust according to the Stacy-Kramers model [62].

In the Bronze and Antique Ages, the Mediterranean ores were used (the isotope ratios averaged for 1224 ores are as follows: ${ }^{208} \mathrm{~Pb} /{ }^{206} \mathrm{~Pb} 2.078 \pm 0.029$, $\left.{ }^{207} \mathrm{~Pb} /{ }^{206} \mathrm{~Pb} 0.841 \pm 0.024\right)$, which were partially overlapped with the compositions of the upper Earth's crust and underlying rocks in the studied region. In the time of the Roman Empire, the main source of ore was the Rio Tinto deposit (currently Spain) with the ${ }^{207} \mathrm{~Pb} /{ }^{206} \mathrm{~Pb}$ isotope ratio equal to $0.861-0.856$. In the Middle Ages, ore was mainly produced in the territory of present-day Germany (Harz, ${ }^{207} \mathrm{~Pb} /{ }^{206} \mathrm{~Pb}=0.847$; Rammelsberg, $\left.{ }^{207} \mathrm{~Pb} /{ }^{206} \mathrm{~Pb}=0.859-0.856\right)$ and England (Derbyshire, ${ }^{207} \mathrm{~Pb} /{ }^{206} \mathrm{~Pb}=0.854-0.842$ ) [5]. The composition of the ores mined presently in Russia and the former USSR countries is shifted toward less radiogenic values and strongly differs from the composition of the local underlying rocks. The comparison of the data presented in Figs. $2 \mathrm{a}$ and $2 \mathrm{~b}$ shows similar evolution trends of the ore and atmospheric-deposition compositions in time. 3400-3600 years ago, the composition of deposition was determined by the averaged composition of the upper Earth's crust while it was close to the composition of the antique Mediterranean ores in the time interval of 1750-1850 years ago (the highest metallurgical activity of the Roman Empire). The similarity of the isotope compositions of the current Russian aerosols; gasoline; and the lead ores of Russia, Kazakhstan, and the Caucasus region indicates the predominance of ore lead used for the production of antiknock additives in the current fallout.

How does such a significant increase in the anthropogenic component of the atmospheric deposition affect the isotopic composition and content of lead in the soils?

Content of mobile and total lead in the recent and submound soils. The highest contents of the total and mobile lead forms and the least radiogenic compositions of the lead were found in the roadside soils along the Moscow-Volgograd motorway (Fig. 3). The total lead concentration is $46 \mathrm{mg} / \mathrm{kg} 10 \mathrm{~m}$ from the road (the point is beyond the scale in Fig. 3A), which exceeds the maximum permissible concentration (MPC) of lead in the soil (according to the Russian hygienic norms GN 2.1.7.2041-06, the lead MPC is 32 $\mathrm{mg} / \mathrm{kg}$ for the soils of settlements). The total lead concentrations in the recent soils (remote from highways) and paleosols do not exceed $13-15 \mathrm{mg} / \mathrm{kg}$ and, hence, are not contaminated according to the existing norms. The results of the study revealed no significant changes in the content of the total lead in the buried soils compared to the recent soil (Figs. 3A, 4). However, it should be noted that the content of total lead is minimum in the profile of the oldest submound soil of the Bronze Age and slightly higher throughout the profile of the recent background soil.

According to the literature data [30,34], the lead of anthropogenic origin is predominantly accumulated in soils in the less strongly bound forms that the "nat- 


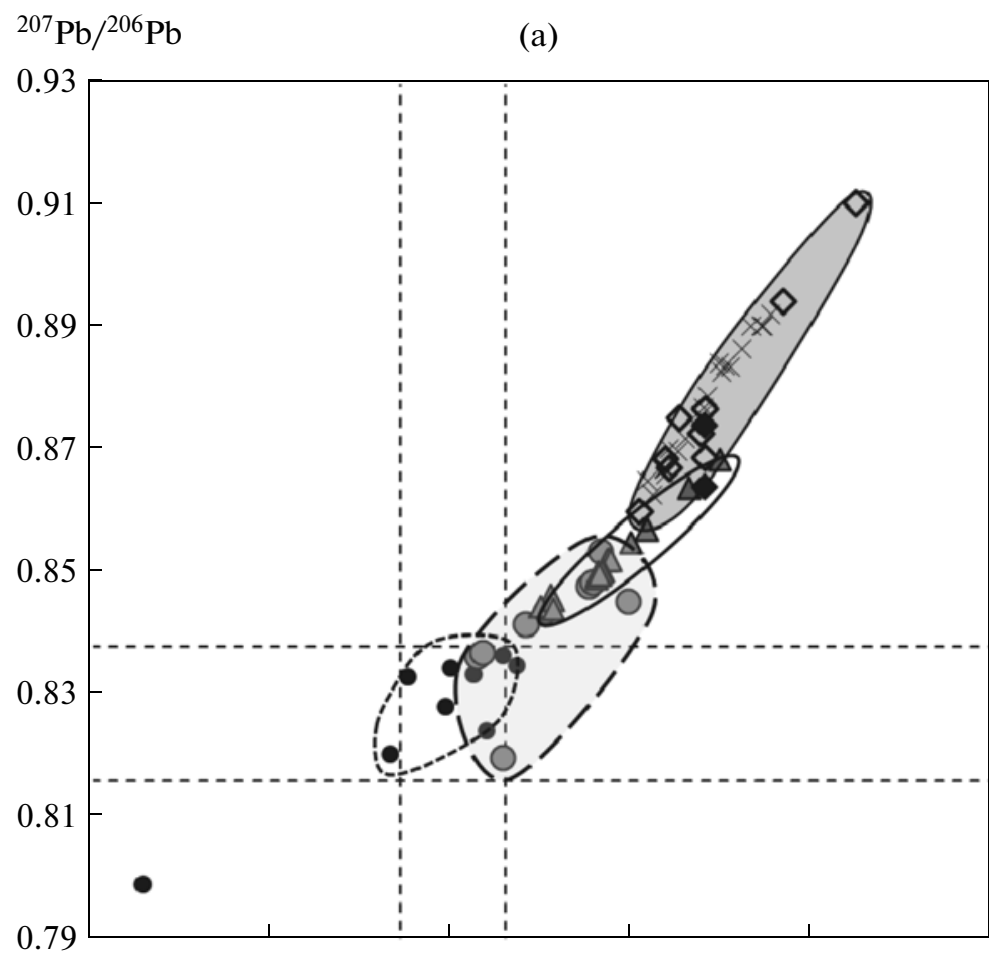

- Peat, Bronze Age, 3400-3600 years ago

- Peat, Iron Age, 1850-1750 years ago

$\Delta$ Peat, Middle Ages, $800-600$ years ago

$\times$ Peat, 1949-2003

$\diamond$ Current aerosols, Russia [43]

- Gasoline, Russia [43]

(b)

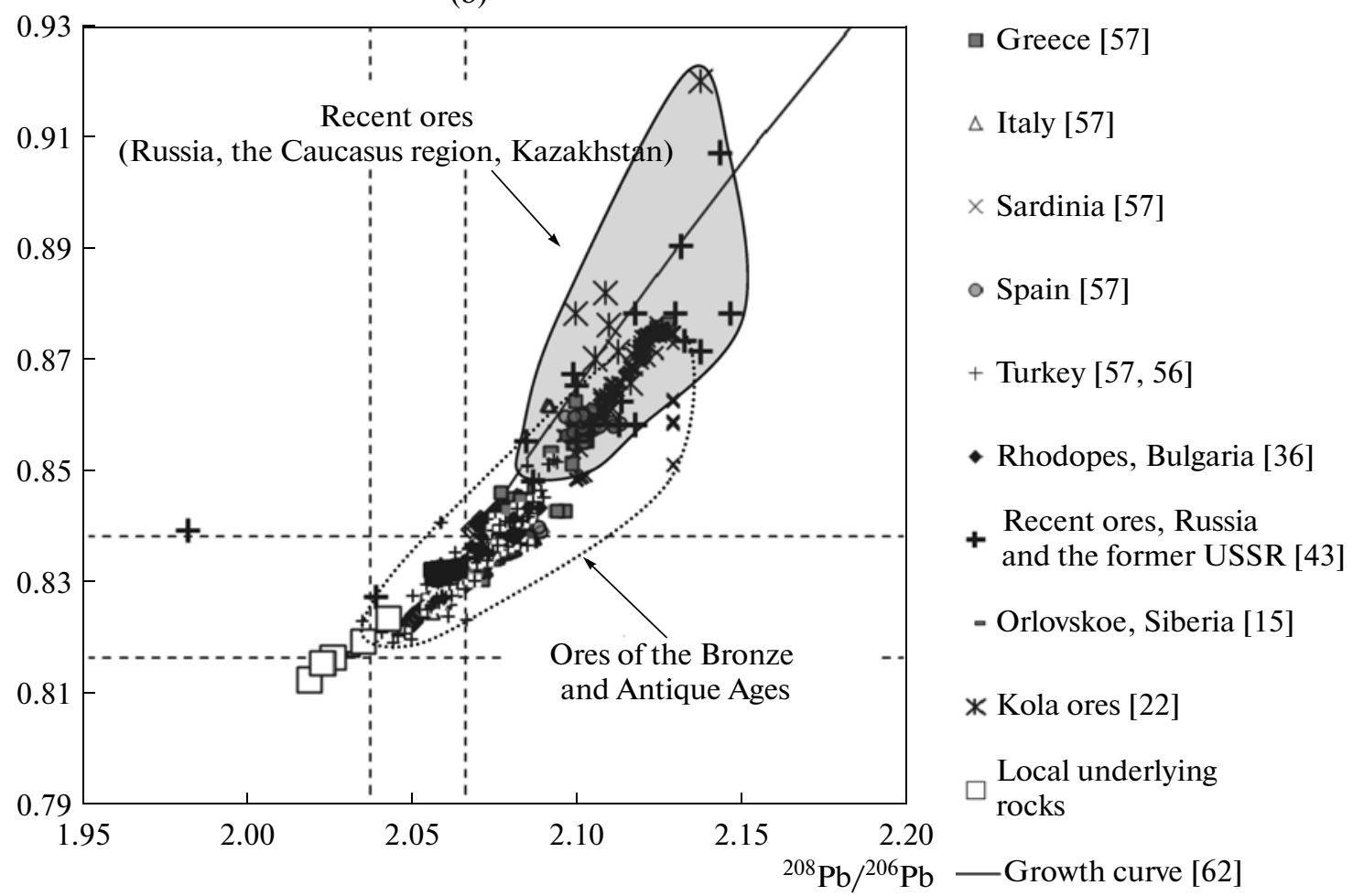

Fig. 2. (a) Evolution of the lead isotope composition in the European atmospheric deposition from data on peat deposits (see Fig. 1) and the compositions of the current Russian aerosols and gasoline. (b) Isotope composition of the lead and the lead-containing ores of the Bronze and Antique Ages and the recent ores of Russia, Kazakhstan, and the Caucasus region. The lead compositions of the underlying rocks in the studied region (cover loess-like sandy loams, diluvial deposits) are shown for comparison. The solid line denotes the growth curve describing the evolution of the Earth's crust isotope composition from the Stacy-Kramers model. The dotted lines denote the range of the lead composition in the upper continental Earth's crust. 


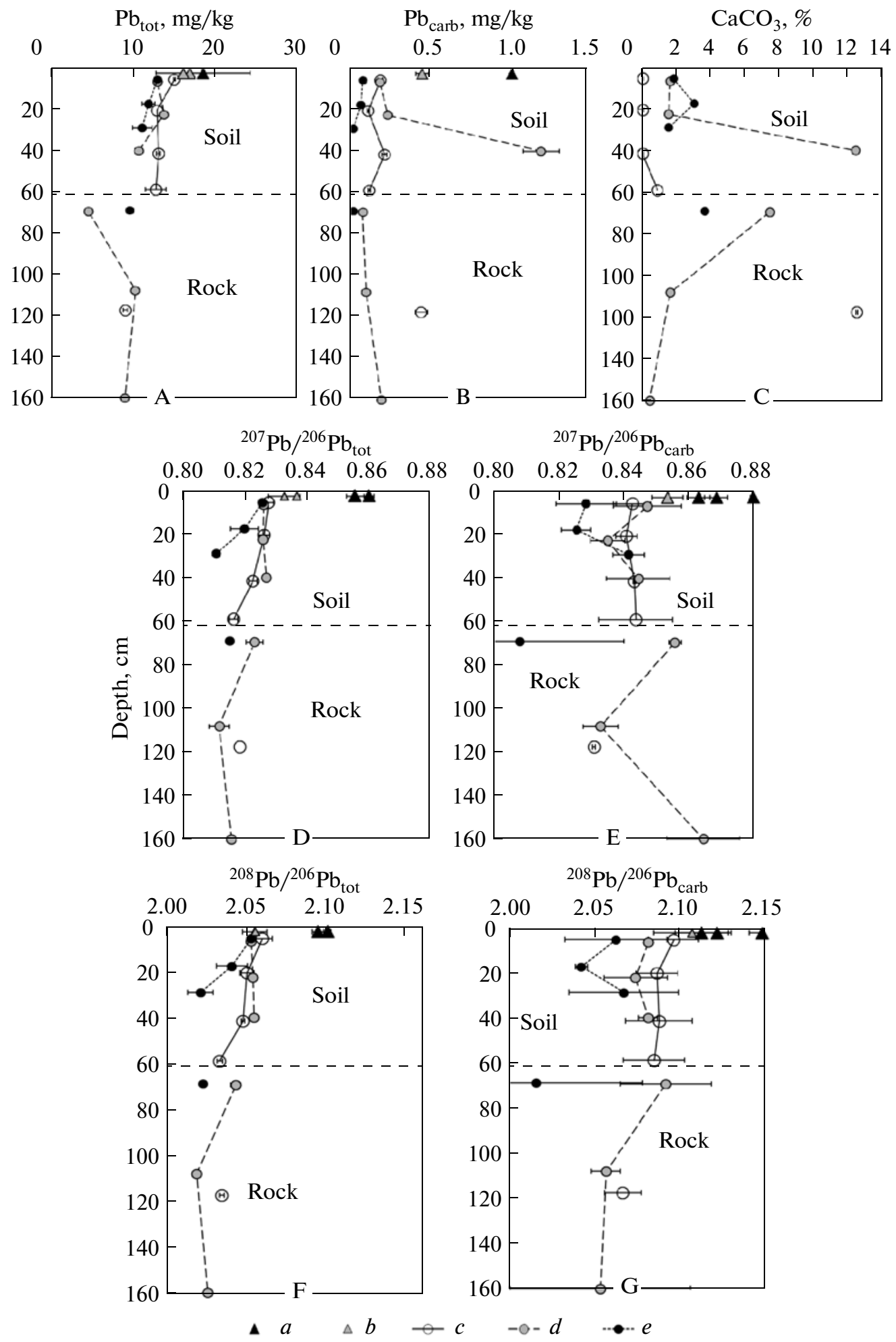

Fig. 3. Contents of the (A) total and (B) mobile (carbonate-bound) lead and the (C) carbonates and the isotope compositions of the $(\mathrm{D}, \mathrm{F})$ total and the $(\mathrm{E}, \mathrm{G})$ carbonate-bound lead in the roadside soils $(a)$ near a motor way, $(b)$ near a local dirt road, $(c)$ in the recent background soils, and in soils buried $(d) 1800$ and $(e) 3500$ years ago. The mean values for the horizons and the standard deviations are shown. 

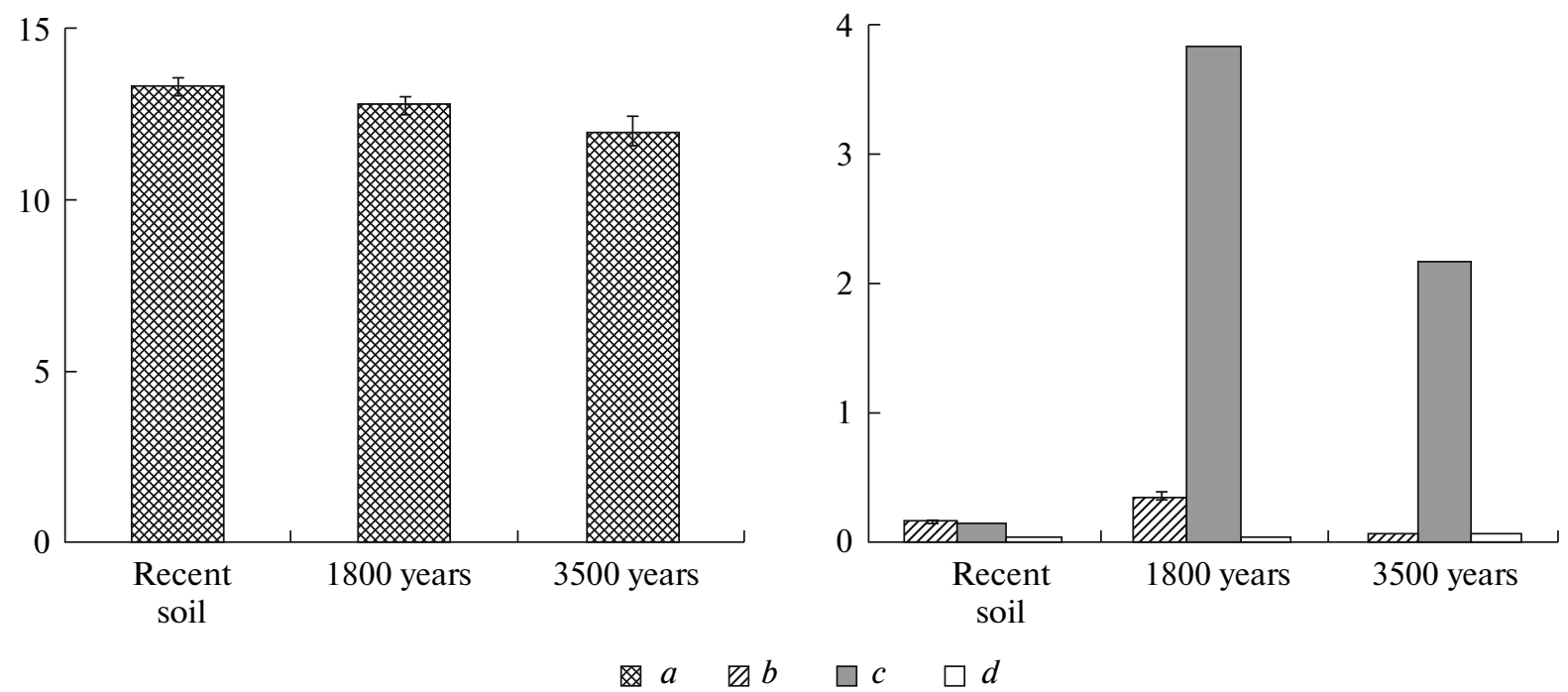

Fig. 4. Weighted average contents of the $(a)$ total and $(b)$ mobile lead $(\mathrm{mg} / \mathrm{kg})$, the $(c)$ carbonates $(\%)$, and the $(d)$ soluble salts $(\%)$ in the A + B horizons of submound (buried 1800 and 3500 years ago) and recent soils.

ural" lead. Hence, the ratio between the total and mobile metal forms can be used as an indicator of the contamination. The results of the studies showed that the samples of the roadside soils were characterized by the highest absolute $(2.7$ and $2.8 \mathrm{mg} / \mathrm{kg}$ at 2 and $5 \mathrm{~m}$ from the road, respectively; the points lie beyond the scale in Fig. 3B) and relative (up to 12\%) contents of the mobile (carbonate-bound) lead form. The minimum values of the mobile lead concentration and its fraction in the total $\mathrm{Pb}$ content in the soil were observed in the profile of the Bronze Age paleosol (Fig. 3B).

The mobile lead was extracted with an ammonium acetate buffer solution with $\mathrm{pH} 4.8$, which release the carbonate-bound and less strongly bound exchangeable lead forms. In contrast to the total lead, whose concentration decreases down the profile, the maximum contents of the mobile lead and its portion in the total lead pool are associated with the horizons containing the maximum amounts of carbonates (the $\mathrm{B} 2 \mathrm{ca}$ horizon of the paleosol, the Dca horizon of the recent soil; Figs. 3B and 3C). However, in the oldest paleosols with sufficient amounts of carbonates throughout the profile, the content of mobile lead is the lowest, while the recent soil with almost no carbonates in its upper horizons contains a larger amount of mobile lead. The weighted average contents of the carbonates, soluble salts, and mobile and total lead in the upper A and B horizons of the submound and recent soils are shown in Fig. 4. The difference in the weighted average concentration of the total lead in the soil chronosequence is insignificant (within 10\%, which is comparable to the error of the determination); however, the concentration of mobile lead varies by several times with the minimum value in the Bronze Age paleosols $(\sim 3500$ years ago $)$ and the maximum value in the late Sarmatian paleosols $(\sim 1800$ years ago). The studies of lake sediments in Sweden showed that more than $50 \%$ of the anthropogenic lead was accumulated in the sediments during the period preceding the industrial revolution, i.e., from 3500 years ago to $1800 \mathrm{AD}$ [9]. At the same time, the buried soils significantly differ from the recent soils by the higher weighted average concentrations of carbonates in the upper horizons of the profile, which can favor the fixation of lead (including its anthropogenic form) in the calcareous horizons due to chemisorption and the formation of carbonates. We found earlier that the climatic conditions of the Lower Volga dry steppes in the time of the Golden Horde (the 8th-14 centuries AD) and in the new and newest times (the 18th-19th centuries) were more humid compared to the 16 th -15 th centuries $\mathrm{BC}$ and the $2 \mathrm{nd}-3$ rd centuries AD [3]. The increase in the atmospheric precipitation resulted in the desalinization of the recent soil profile, the decrease in the carbonate concentration in its upper part, the lowering of the depth of the calcareous horizon, and the increase of the lead's mobility. As a result, even at the high anthropogenic load on the recent soil, the concentration of mobile lead (probably enriched with the anthropogenic component) in the recent soil can be lower than in the Sarmatian soil (Fig. 4) buried 1800 years ago at the rise of antique metallurgy. The fact that the content of the carbonate-bound lead is apparently determined not only by the presence of carbonates but also by the input of mobile lead from anthropogenic sources is reflected in the relatively low values of the correlation coefficient (simple linear regression, the roadside soils are not included) between the content of carbonates, the content of mobile lead, and its fraction in the total lead pool ( $R^{2} 0.49$ and 0.56 , respectively). 

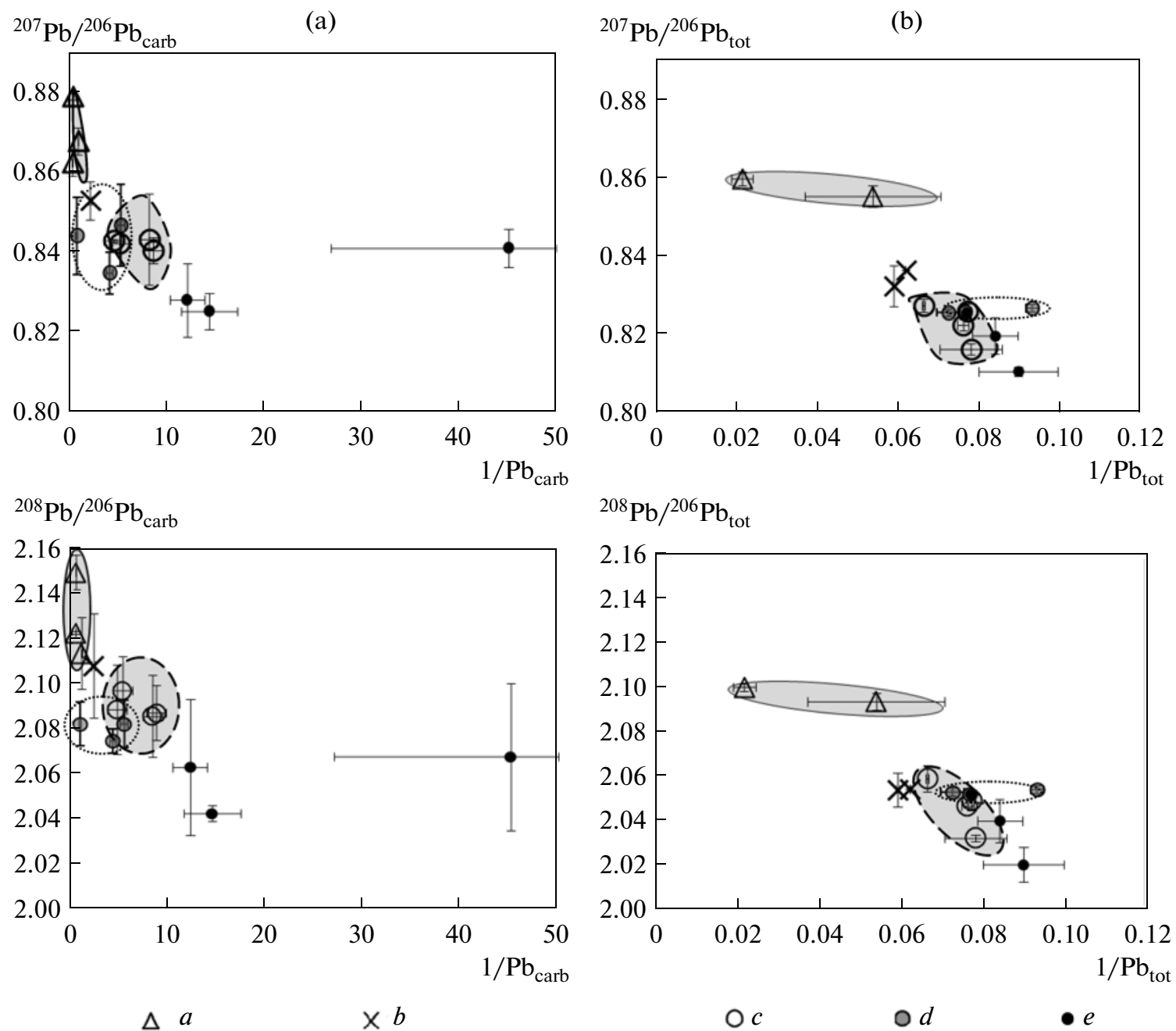

Fig. 5. Isotopic composition of the lead as a function of its concentration in the roadside soils $((a)$ near a motor way, $(b)$ near a dirt road, $(c)$ in the recent background soils, and in soils buried (d) 1800 and (e) 3500 years ago for (a) the carbonate-bound and (b) the total forms.

Isotopic composition of lead. The isotopic composition of the total lead in the roadside soils is shifted toward less radiogenic values typical for the lead of the recent aerosols and Russian gasoline [43] (Figs. 3D, 3F). The highest shift is observed in the soils near the MoscowVolgograd motorway with intense traffic and, to a lesser degree, at a local country dirt road about $30 \mathrm{~m}$ from the mounds.

No statistically significant difference in the total lead isotope composition was found between the A horizons of the background recent soil (remote from roads) and the paleosols. In addition, there are almost no significant differences in the isotope composition between the recent and Sarmatian soils throughout the profile. These soils are characterized by less radiogenic isotope ratios in their lower horizons compared to the paleosol of the Bronze Age (Figs. 3D, 3F), which can result from both the penetration of anthropogenic lead and the natural heterogeneity of the parent rocks. The total lead in the Bronze-Age soil is characterized by a change in the isotopic composition from less radiogenic to more radiogenic values down the profile. By analogy with the peat and bottom sediments, such a shift of the isotope composition with depth is interpreted as a result of changes in the portion of the less radiogenic lead of anthropogenic (atmospheric) origin with regard to the metal inherited from the parent rocks [9]. However, in our case, this is most evident in the soil buried 3500 years ago, in the time of the lowest anthropogenic impact. A similar change in the isotope composition with depth is less pronounced in the recent soil and is almost imperceptible in the Sarmatian paleosol. We think that the profile change in the isotope ratios of the total lead observed in the paleosols can be due to natural reasons and is not always a sign of an anthropogenic effect. This can be related, e.g., to the difference between the isotopic compositions of the transboundary atmospheric lead of natural origin 


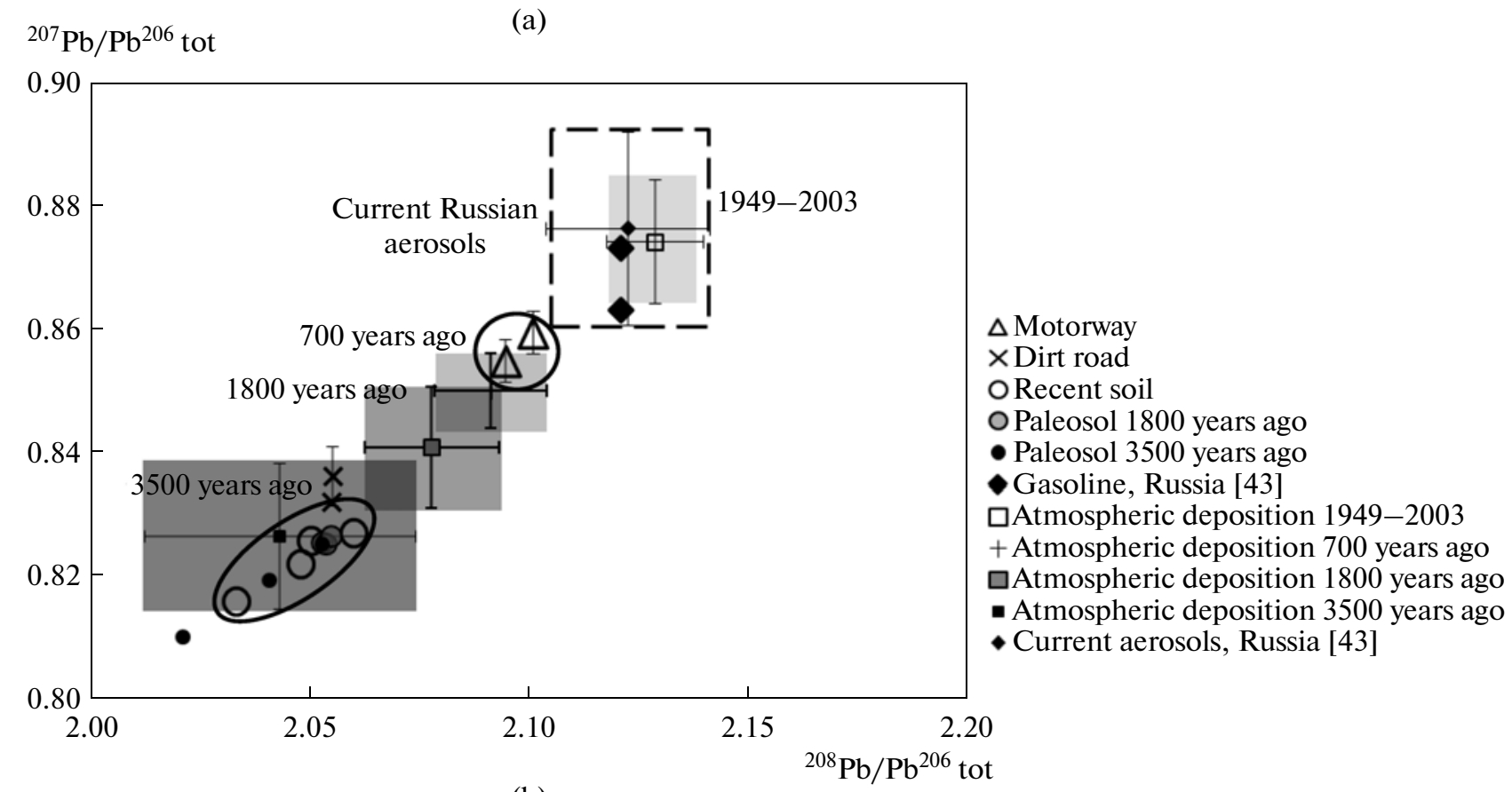

${ }^{207} \mathrm{~Pb} / \mathrm{Pb}^{206}$ carb

(b)

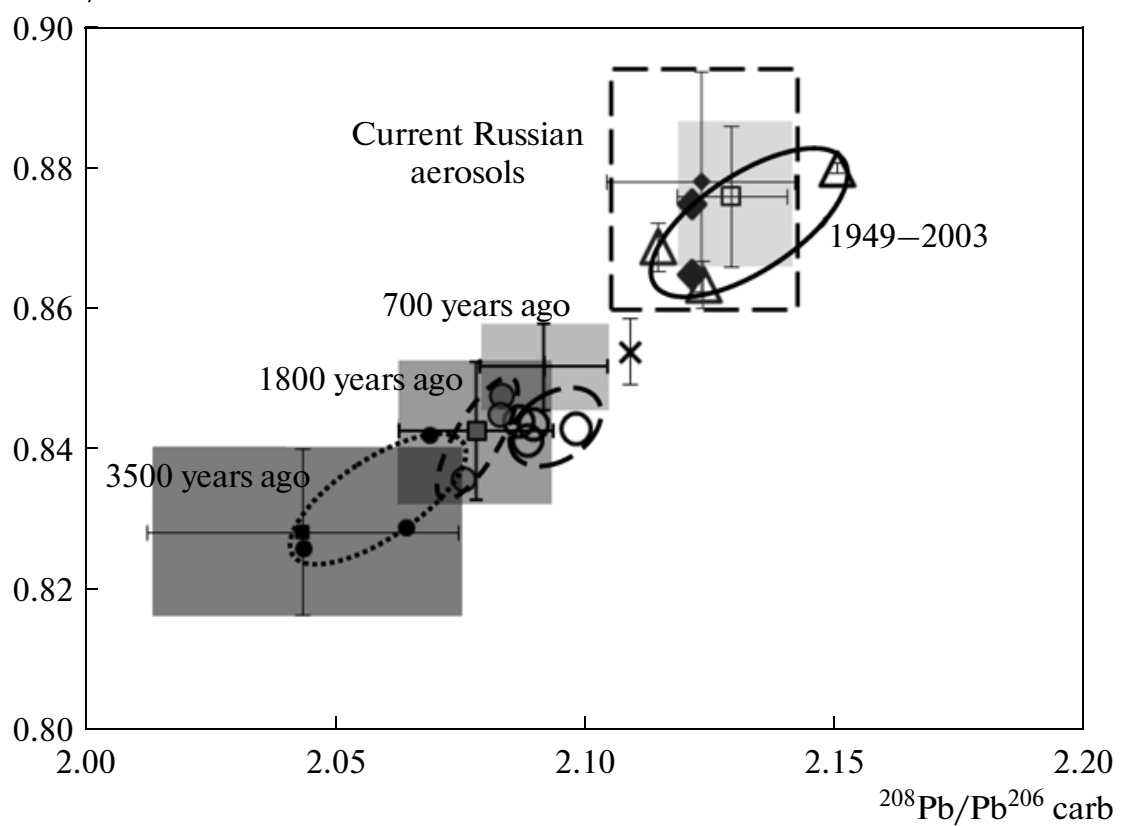

Fig. 6. Changes in the isotopic composition of the lead in the atmospheric deposition and soils over 3500 years (for the explanations, see in the text).

(resulting from the mixing of lead from different remote sources in the atmosphere) and the lead from the local parent rocks. Changes in the total lead isotopic composition at the formation of the soil profile due to the different stabilities of the accessory and rockforming minerals (with different lead isotope compositions) under weathering can also contribute. Changes in the lead isotope composition during the weathering of soils and rocks are described by Erel et al. [16] and Harlavan et al. [24].
The absolute and relative contents of the mobile form of lead increase in contaminated soils; therefore, it can be supposed that its isotope composition will be more susceptible to the anthropogenic effect than that of the total lead.

The isotopic composition of the mobile lead in roadside soils is even more shifted toward less radiogenic values compared to the total lead; in the case of the motor way, it is close to the composition of the lead from the recent aerosols, the lead ores of the former 
USSR, and Russian gasoline [43] (Figs. 3E, 3G). The comparison of the background recent soil (remote from roads) and the paleosols shows a shift in the mean values of the isotope ratios $\left({ }^{207} \mathrm{~Pb} /{ }^{206} \mathrm{~Pb}\right.$ and ${ }^{208} \mathrm{~Pb} /{ }^{206} \mathrm{~Pb}$ ) toward less radiogenic values when going from the old to the recent soil (Figs. 3E, 3G).

The relationship between the isotopic composition of the lead and its content in the soil is shown in Fig. 5. A pronounced increase in the ${ }^{207} \mathrm{~Pb} /{ }^{206} \mathrm{~Pb}$ and ${ }^{208} \mathrm{~Pb} /{ }^{206} \mathrm{~Pb}$ ratios is observed for the mobile lead when going from the oldest soil buried $\sim 3500$ years ago to the recent background soil and then to the roadside soils. The field of the lead's composition in the Sarmatian paleosol (1800 years ago) is partially overlapped by the field of the recent soil (Fig. 5a). Signs of the same trend are also present in the case of the total lead (Fig. 5b); however, only the roadside soils clearly differ in their isotopic composition from the other soils, whose compositions are largely overlapped. The lowest content of mobile lead and the isotopic composition the most remote from that of anthropogenic lead are observed in the profile of the paleosol isolated by the mound ground from atmospheric fallout for the longest time period (about 3500 years) (Fig. 5). The closest agreement and the partial overlapping of the isotopic compositions of the total and mobile forms were revealed in this paleosol, while the isotopic compositions of the total and mobile lead in the recent and buried for 1800 years soils are clearly different. The mobile form is characterized by a shift of the isotopic composition toward the values typical for lead ores and atmospheric aerosols. The atmospheric (including anthropogenic) component is apparently predominant in its composition, while the total form to a greater extent inherits the composition of the parent rock.

As was shown earlier (Figs. 1, 2), the isotopic composition of the atmospheric lead deposition in Europe shifted in time toward less radiogenic values due to an increase in the anthropogenic component. We compared the time trends in the evolution of the lead composition in the soils and atmospheric deposition (Fig. 6). The shaded areas denote the mean values ( \pm standard deviation) of the atmospheric deposition's composition from the data on European peat cores shown in Fig. 2 and corresponding to the burial time of the studied submound soils, as well as to the Middle Ages period about 700 years ago (the 13th-14th centuries AD) and the period of 1949-2003. The composition of the current aerosols in Russia is also shown. The composition of the atmospheric deposition in Europe during the post-WWII period well agrees with the data on the compositions of the current Russian aerosols and gasoline. It can be seen (Fig. 6b) that the composition of the mobile lead is shifted with time, as well as that of the atmospheric deposition, toward less radiogenic isotopic ratios. The compositions of the mobile lead in the soils 3500 and 1800 years ago and in the modern roadside soils correspond to the composition of the lead from the atmospheric deposition of the corresponding time periods. However, the lead's composition in the recent background soil is more radiogenic than in the current atmospheric deposition and is close to that of the lead in the Sarmatian paleosol. This can be related to the high mobility of lead in the recent soil compared to the paleosols and to the partial removal of the recent anthropogenic lead beyond the soil profile.

A different situation is observed for the total lead. The change in the composition of the atmospheric lead deposition little affected the isotopic composition of the total lead in the soils, except for that of the roadside soils, which significantly shifted toward the anthropogenic compositions (Fig. 6a). This demonstrates the local character of the contamination of the recent soils in the region studied, whose source is motor transport.

\section{CONCLUSIONS}

(1) Anthropogenic $\mathrm{Pb}$ in atmospheric deposition in the Lower Volga dry steppes could originate from remote and local sources. Literature data on the historical lead deposition in Europe (based on ombrotrophic peat bogs) and data on the isotopic composition of lead in ores, which could serve as potential source of lead during different periods over the past millennia, were analyzed. Changes in the isotopic composition of the atmospheric lead fallout with time toward less radiogenic values were revealed, which are due to an increase in the anthropogenic (ore) component and changes in the sources of the ore lead with time.

(2) The effect of the increase in the anthropogenic component of the atmospheric lead deposition recorded everywhere in Europe since the Bronze Age on the contamination of chestnut soils was assessed. For the first time, paleosols buried under a BronzeAge mound were used as a reference point for assessing the scale of the contamination. The contents and isotopic compositions of the mobile and total lead were determined in submound paleosols of different ages and their recent remote and roadside analogues. The studies revealed an increase in the content of the mobile lead and the shifting of its isotopic composition toward less radiogenic values (typical for lead of the current Russian atmospheric deposition, ores, and gasoline) when going from the Bronze Age paleosol (16th-15th centuries BC) to the recent soil. The isotopic composition of the mobile lead in the paleosol of the late Bronze Age is more inherited from the parent rock than in the soils of the following epochs, where it was enriched with the less radiogenic component throughout the profile.

(3) The effect of the anthropogenic component is traced in the analysis of the mobile lead, but it is almost imperceptible when comparing of the total concentrations and the isotopic ratios of the metal. In 
these terms, the recent background soils remote from roads and the paleosols of the late Sarmatian age (2nd-3rd centuries AD) are not more contaminated with lead compared to the Bronze Age paleosols (16th-15th centuries BC). An exception is provided by the recent roadside soils characterized by elevated contents and a significantly less radiogenic isotopic composition of the mobile and total lead. The lead contamination of the studied soils is manifested locally near roads and is due to motor transport.

We note that the conclusions drawn in our study are based on the assumption that mounds $50-60 \mathrm{~cm}$ high in fact isolate the paleosols from the current atmospheric lead deposition. Our further work will be focused on the verification of this hypothesis in the study of lead migration in steppe chestnut soils.

\section{ACKNOWLEDGMENTS}

We thank the personnel and students of the archeological expedition of Volgograd State University for assistance in the field work; P. Candaudap, G. Durbe, and M. Henri (LMTG, Toulouse, France) for assistance in the organization and fulfillment of the analytical studies; M. Lefevre for encouragement and hospitality; M.E. Schylander (Stockholm University) for data provided on peat deposits; and M. Miley (Stockholm University) for valuable discussions.

This work was supported in part by the Russian Foundation for Basic Research (project no. 09-0400233), the French National Center for Scientific Research (project nos. 09-05-91058-CNRS_a, PICS and no. 4982), and the Program of Basic Research of the Presidium of the Russian Academy of Sciences (project nos. 4 and 25).

\section{REFERENCES}

1. A. V. Borisov, T. S. Demkina, and V. A. Demkin, Paleosols and Climate of the Ergeni Upland in the Bronze Age (4th-2nd millennia BC) (Nauka, Moscow, 2006) [in Russian].

2. V. A. Demkin, A. V. Borisov, T. S. Demkina, et al., Volga-Don Steppes in the Ancient Time and Middle Ages (Materials of Pedoarchaeological Studies) (SYNCHROBOOK, Pushchino, 2010) [in Russian].

3. V. A. Demkin, T. S. Demkina, T. E. Khomutova, N. N. Kashirskaya, A. V. Borisov, M. V. El’tsov, "Integration of paleopedology and archaeology in the study of nature and society," in Soil Processes and the Spatiotemporal Organization of Soils (Nauka, Moscow, 2006), pp. 116-140 [in Russian].

4. G. Faure, Principles of Isotope Geology (John Wiley, New York, 1986).

5. S. Alfonso, F. Grousset, L. Masse, and J.-P. Tastet, "A European lead isotope signal recorded from 6000 to 300 years bp in costal marshes (SW France)," Atmos. Environ. 35, 3595-3605 (2001).

6. C. J. Allèrge, Isotope Geology (Cambridge University Press, 2005).
7. Y. Asmerom and S. B. Jacobsen, "The $\mathrm{Pb}$ isotopic evolution of the Earth-inferences from river water suspended loads," Earth Planet. Sci. Lett. 115, 245-256 (1993).

8. R. Bindler, M.-L. Brannval, and I. Renberg, "Natural lead concentrations in Pristine boreal forest soils and past pollution trends: a reference for critical load models," Environ. Sci. Technol. 33, 3362-3367 (1999).

9. R. Bindler, I. Renberg, and J. Klaminder, "Bridging the gap between ancient metal pollution and contemporary biogeochemistry," J. Paleolimnol. 40, 755-770 (2008).

10. G. R. Bourton, K. J. R. Rosman, J. P. Candeloni, L. J. Burn, C. F. Bourton, S. M. Hong, "The impact of climatic conditions on $\mathrm{pb}$ and sr isotopic ratios found in Greenland Ice 7-150 Kyr BP,” Earth Planet. Sci. Lett. 239, 557-566 (2007).

11. M.-L. Bränvall, R. Bindler, I. Renberg, O. Emteryd, J. Bartniki, K. Billstrom, "The medieval metal industry was the cradle of modern large-scale atmospheric lead pollution in northern Europe," Environ. Sci. Technol. 33, 4391-4395 (1999).

12. G. L. Cumming and J. R. Richards, "Ore lead isotope ratios in a constantly changing Earth," Earth Planet. Sci. Lett. 28, 155-171 (1975).

13. F. De Vleeschouwer, L. Gerard, C. Goormaghtigh, and N. Mattielli, G. Le Roux, and N. Fagel, "Atmospheric lead and heavy metal pollution records from a Belgian peat bog spanning the last two millennia: human impact on a regional to global scale," Sci. Total Environ. 377, 282-295 (2007).

14. V. A. Demkin, I. V. Sergatskov, T. S. Demkina, and A. V. Borisov, "Paleosols, paleoenvironment, and ancient societies in the steppes of southern Russia," Eur. Soil Sci. 35 (Suppl. 1), 61-67 (2002).

15. A. Dolgopolova, D. J. Weiss, R. Seltmann, B. Kober, T. F. D. Mason, B. Coles, C. J. Stanley, "Use of isotope ratios to assess sources of $\mathrm{Pb}$ and $\mathrm{Zn}$ dispersed in the environment during mining and ore processing within the Orlovka-Spokoinoe mining site (Russia)," Appl. Geochem. 21, 563-579 (2006).

16. Y. Erel, Y. Harlavan, and J. D. Blum, "Lead isotope systematics of granitoid weathering," Geochim. Cosmochim. Acta 58 (23), 5299-5306 (1994).

17. Y. Erel, A. Veron, and L. Halicz, "Tracing the transport of anthropogenic lead in the atmosphere and in soils using isotopic ratios," Geochim. Cosmochim. Acta 61 (21), 4495-4505 (1997).

18. J. G. Farmer, L. J. Eades, A. B. MacKenzie, A. Kirika, and T. E. Baily-Watts, "Stable lead isotope record of lead pollution in Loch Lomond sediments since 1630 A.D," Environ. Sci. Technol. 30, 3080-3083 (1996).

19. H.-E. Gäbler and A. Suckow, "Chronology of anthropogenic heavy-metal fluxes and $\mathrm{Pb}$ isotopic ratios derived from radiometricaly dated lake sediments in northern Germany," Water Air Soil Pollut. 144, 243262 (2003).

20. C. Gallon, M. A. Ranville, C. Conway, W. Landing, C. S. Buck, P. M. Morton, R. Flegal, "Asian industrial lead inputs to the North Pacific evidenced by lead concentrations and isotopic compositions in surface waters 
and aerosols," Environ. Sci. Technol. 45, 9874-9882 (2011)

21. U. K. Haack, F. H. Gutsche, K. Plessow, and H. Heinrichs, "On the isotopic composition of $\mathrm{Pb}$ in cloud waters in central Germany: a source discrimination study," Water Air Soil Pollut. 19, 261-288 (2002).

22. U. K. Haack, H. Heinrichs, F. H. Gutsche, and K. Plessow, "The isotopic composition of anthropogenic $\mathrm{Pb}$ in soil profiles of northern Germany: evidence for pollutant $\mathrm{Pb}$ from a continent-wide mixing system," Water Air Soil Pollut. 150, 113-134 (2003).

23. U. K. Haack, B. Kienholz, C. Reimann, J. Schneider, E. F. Stumpel, "Isotopic composition of lead in moss and soil of the European Arctic," Geochim. Cosmochim. Acta 68 (12), 2613-2622 (2004).

24. Y. Harlavan, Y. Erel, and J. D. Blum, "Systematic changes in lead isotopic composition with soil age in glacial granitic terrains," Geochim. Cosmochim. Acta 62 (1), 33-46 (1998).

25. S. R. Hemming and S. M. McLennan, "Pb isotope compositions of modern deep sea turbidities," Earth Planet. Sci. Lett. 184, 489-503 (2001).

26. S. Hong, J. P. Candelone, C. C. Patterson, and C. F. Boutron, "History of ancient copper smelting pollution during roman and medieval times recorded in Greenland Ice," Science 272, 246-249 (1996).

27. J. F. Hopper, H. B. Ross, W. T. Sturges, and L. A. Barrie, "Regional Source discrimination of atmospheric aerosols in Europe using the isotopic composition of lead," Tellus, 45-60 (1991).

28. I. Ilyin, O. Rozovskaya, O. Travnikov, W. Aas, J. P. Hettelingh, G. J. Reinds, "Heavy metals: transboundary pollution of the ånvironment," EMEP Status Report 2, 94 (2008).

29. International Lead and Zinc Study Group, Lead and Zink Statistics: Monthly Bull. 39 (8) (1999).

30. P. E. Jensen, L. M. Ottosen, and A. J. Pedersen, "Speciation of $\mathrm{Pb}$ in industrially polluted soils," Water Air Soil Pollut. 170, 359-382 (2006).

31. O. S. Khokhlova, A. A. Khokhlov, and N. L. Morgunova, "Evolution of soils in the Holocene chronosequence in the Ural River valley (Cis-Ural steppe)," Eur. Soil Sci. 37 (Suppl. 1), 525-535 (2004).

32. J. Klaminder, R. Bindler, J. Rydberg, and I. Renberg, "Is there a chronological record of atmospheric mercury and lead deposition preserved in the mor layer (O-horizon) of boreal forest soils," Geochim. Cosmochim. Acta 72, 703-712 (2008).

33. J. Klaminder, I. Renberg, R. Bindler, and O. Emteryd, "Isotopic trends and background fluxes of atmospheric lead in northern Europe: analyses of three ombrotrophic bogs from south Sweden," Glob. Biogeochem. Cycles 17 (2003).

34. M. Komarek, V. Ettler, V. Chrastny, and M. Mihaljevic, "Lead Isotopes in environmental sciences: a review," Environ. Intern. 34, 562-577 (2008).

35. J. D. Kramers and I. N. Tolstihim, "Two terrestrial lead isotope paradoxes, forward transport modelling, core formation and the history of the continental crust," Chem. Geol. 139, 75-110 (1997).

36. I. Kuleffa, I. Ilieva, E. Pernickaa, and D. Gergova, "Chemical and lead isotope compositions of lead arte- facts from ancient Thracia (Bulgaria),” J. Cultur. Heritage 7, 244-256 (2006).

37. M. E. Kylander, J. Klaminder, R. Bindler, and D. J. Weiss, "Natural lead isotope variations in the atmosphere," Earth Planet. Sci. Lett. 290, 44-53 (2010).

38. M. E. Kylander, D. Weiss, and B. Kobler, "Two high resolution terrestrial records of atmospheric $\mathrm{Pb}$ dposition from New Brunswick, Canada, and Loch Laxford, Scotland," Sci. Total Environ. 4, 1644-1657 (2009).

39. M. E. Kylander, D. J. Weiss, A. Martinez Cortizas, B. Spiro, R. Garcia-Sanchez, and B. J. Coles, "Refining the pre-industrial atmospheric $\mathrm{Pb}$ isotope evolution curve in Europe using 8000-year old peat core from NW Spain,” Earth Planet. Sci. Lett. 240, 467-485 (2005).

40. R. Millot, C.-J. Allegre, J. Gaillardet, and S. Roy, "Lead isotope systematics of major river sediments: a new estimate of the $\mathrm{Pb}$ isotopic composition of the upper continental crust," Chem. Geol. 203, 75-90 (2004).

41. F. Monna, D. Galop, L. Carozza, M. Tual, A. Beyrie, F. Marembert, C. Chateau, J. Dominik, F. E. Grousset, "Environmental impact of early basque mining and smelting recorded in high ash minerogenic peat deposit," Sci. Total Environ. 327, 197-214 (2004).

42. F. Monna, J. Lancelot, I. W. Croudace, A. B. Cundy, J. T. Lewis, "Pb isotopic composition of airborne particulate material from france and the southern United Kingdom: implication for $\mathrm{Pb}$ pollution sources in urban areas," Environ. Sci. Technol. 31, 2277-2286 (1997).

43. H. Mukai, T. Machida, A. Tanaka, P. V. Yelpatievskiy, M. Uematsu, "Lead isotope ratios in the urban air of eastern and central Russia," Atmos. Environ. 35, 2783-2793 (2001).

44. M. Murozumi, T. J. Chow, and C. C. Patterson, "Chemical concentrations of pollutant lead aerosols, terrestrial dusts and sea salts in Greenland and Antarctic snow strata," Geochim. Cosmochim. Acta 33, 1247-1294 (1969).

45. M. Novak, Y. Erel, L. Zemanova, S. H. Bottrell, M. Adamova, "A comparison of lead pollution record in sphagnum peat with known historical $\mathrm{Pb}$ emission rates in British Isles and the Czech Republic," Atmos. Environ. 42, 8997-9006 (2008).

46. J. O. Nriagu, "A global assessment of natural sources of atmospheric trace metals," Nature 338, 47-49 (1989).

47. J. O. Nriagu and J. M. Pachyna, "Quantitative assessment of worldwide contamination of air, water, and soils by trace metals," Nature 333, 134-139 (1988).

48. E. G. Pacyna and J. M. Pacyna, "An assessment of global and regional emissions of trace metals to the atmosphere from anthropogenic sources worldwide," Environ. Rev. 9, 269-298 (2001).

49. J. M. Pachyna, T. M. Scholtz, and Y.-F. Li, "Global budget of trace metal sources," Environ. Rev. 3, 145159 (1995).

50. C. Reimann, B. Flem, K. Fabian, M. Birke, A. Ladenberger, P. Negrel, A. Demetriades, J. Hoogewerff, "The GEMAS project team. Lead and lead isotopes in agricultural soils of Europe-the continental perspective," Appl. Geochem. 27, 532-542 (2012). 
51. I. Renberg, M.-L. Brannvall, R. Bindler, and O. Emteryd, "Atmospheric lead pollution history during four millennia (2000 BC to 2000 AD) in Sweden," AMBIO 29 (3), 150-156 (2000).

52. I. Renberg, M.-L. Brannvall, R. Bindler, and O. Emteryd, "Stable lead isotopes and lake sediments - a useful combination for study of atmospheric lead pollution history," Sci. Total Environ. 292, 45-54 (2002).

53. K. J. R. Rosman, W. Chisholm, S. Hong, J. P. Candelone, C. F. Bourton, "Lead from Cartagianian and Roman Spanish mines isotopically identified in Greenland ice dated from $600 \mathrm{BC}$ to $300 \mathrm{AD}$," Environ. Sci. Technol. 31, 3413-3416 (1997).

54. K. J. R. Rosman and P. D. P. Taylor, "Report of the IUPAC subcommittee for isotopic abundance measurements," Pure Appl. Chem. 71, 1593-1607 (1999).

55. D. F. Sangster, P. M. Outridge, and W. J. Davis, "Stable lead isotope characteristics of lead ore deposits of environmental significance," Environ. Rev. 8, 115-147 (2000).

56. E. V. Sayre, E. C. Joel, M. J. Blackman, K. F. Yener, H. Oezbal, "Stable lead isotope studies of Black Sea Anatolian ore sources and related Bronze Age and Phrygian artefacts from nearby archaeological sites. appendix: new Central Taurus ore data," Archaeometry 43, 77-115 (2001).

57. B. Scaife, "Database of lead isotope ratios for ores collected from around the Mediterranean, papers published between 1987 and 1997," http://brettscaife. net/lead/data/index.html.

58. D. M. Settle and C. C. Patterson, "Lead in Albacore: guide to lead pollution in Americans," Science 207, 1167-1176 (1980).

59. H. Shiharata, W. Elias, and C. C. Patterson, "Chronological variations in concentrations and isotopic com- positions of anthropogenic atmospheric lead in sediments of a remote subalpine pond," Geochim. Cosmochim. Acta 44, 149-162 (1980).

60. W. Shotyk, P. Blaser, A. Grunig, and A. K. Cheburkin, "A new approach for quantifying cumulative, anthropogenic, atmospheric lead depositions using peat cores from bogs: $\mathrm{Pb}$ in eight Swiss peat bog profiles," Sci. Total Environ. 249, 281-295 (2000).

61. W. Shotyk, D. Weiss, J. D. Kramers, R. Frei, A. K. Cheburkin, M. Gloor, S. Reese, "Geochemistry of the peat bog at Etang De La Gruere, Jura Mountains, Switzerland, and its record of atmospheric $\mathrm{Pb}$ and lithogenic trace metals (Sc, Ti, Y, Zr, and REE) since 12270 14C Yr BP," Geochim. Cosmochim. Acta 65, 2337-2360 (2001).

62. J. S. Stacey and J. D. Kramers, "Approximation of terrestrial lead isotope evolution by a two stage model," Earth Planet. Sci. Lett. 26, 207-221 (1975).

63. M. Tatsumoto, R. J. Knight, and C. J. Alleger, "Time differences in the formation of meteorites as determined from the ratio of lead-207 to lead-206," Science 180, 1279-1283 (1973).

64. M. F. Thirlwall, M. A. M. Gee, R. N. Taylor, and B. J. Murton, "Mantle components in Iceland and adjacent ridges investigated using double-spike $\mathrm{Pb}$ isotope ratios," Geochim. Cosmochim. Acta 68, 361-386 (2004).

65. P. Vallelonga, P. Gabrielli, K. J. R. Rosman, C. Barbante, C. F. Bourton, "A 220 Kyr record of $\mathrm{Pb}$ isotopes at Dome C Antarctica from analyses of the EPICA ice core," Geophys. Res. Lett. 32, 32 (2005).

66. D. Weiss, W. Shotyk, and O. Kempf, "Archives of atmospheric lead pollution," Naturwissenschaften 86, 262275 (1999).

Translated by K. Pankratova 